\title{
Enantioselective Total Synthesis of (+)- Gigantecin: Exploiting the Asymmetric Glycolate Aldol Reaction
}

Michael T. Crimmins* and Jin She

Department of Chemistry, Venable and Kenan Laboratories of Chemistry, University of North

Carolina at Chapel Hill, Chapel Hill, NC 27599-3290

crimmins@email.unc.edu

Supporting Information

${ }^{1} \mathrm{H}$ and ${ }^{13} \mathrm{C}$ NMR data 


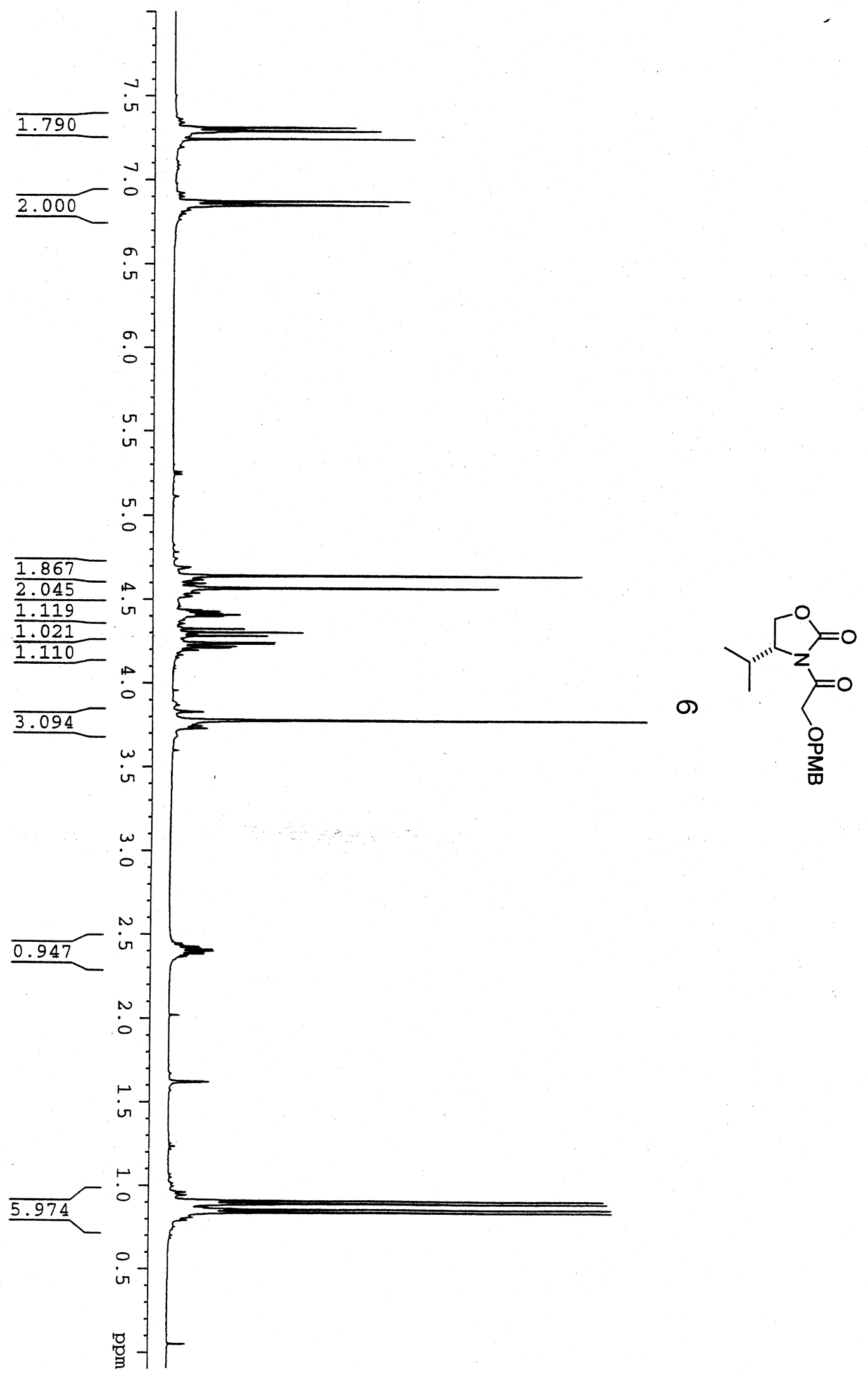



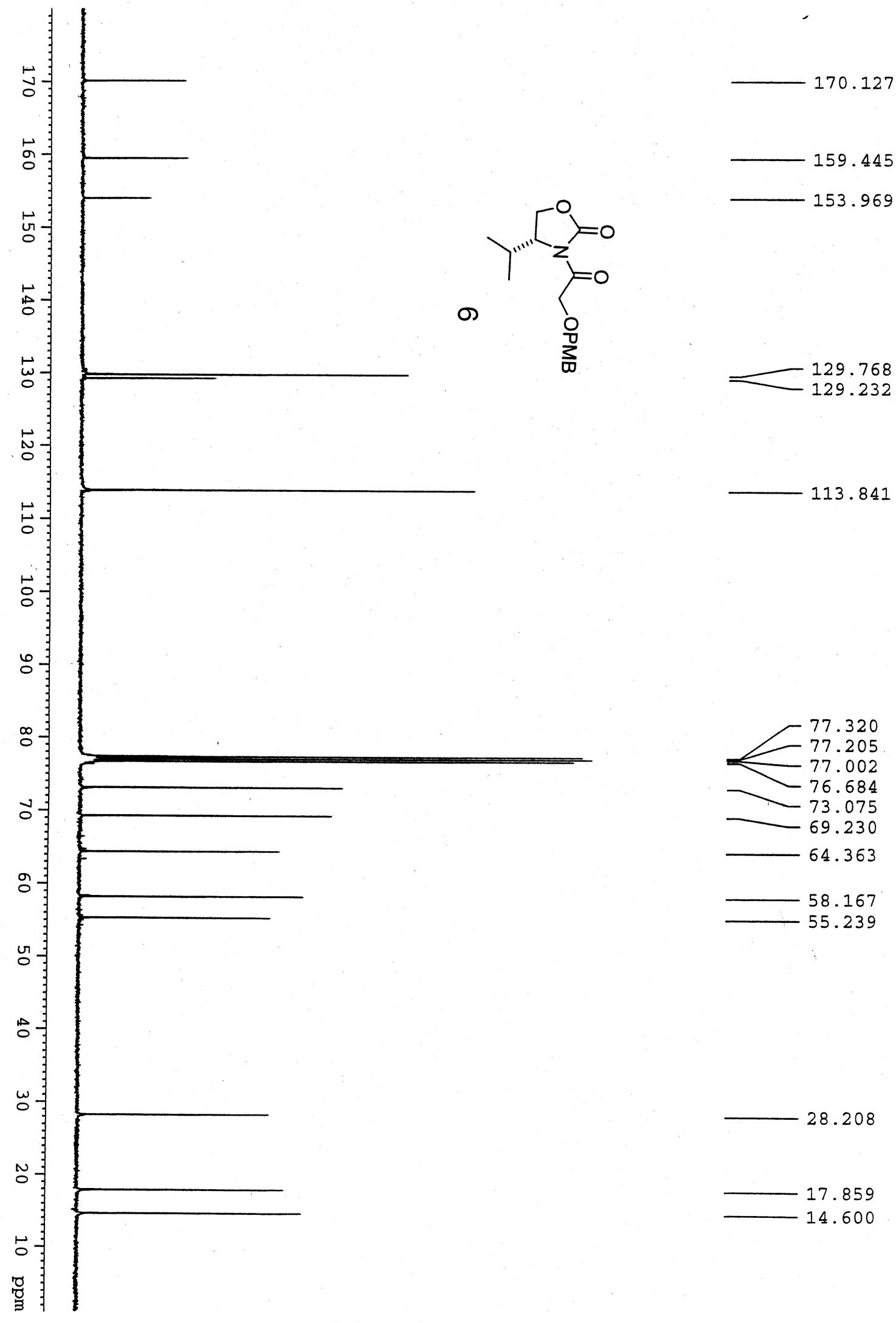

129.232

113.841

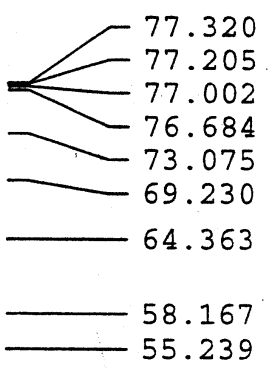

28.208

17.859

14.600 


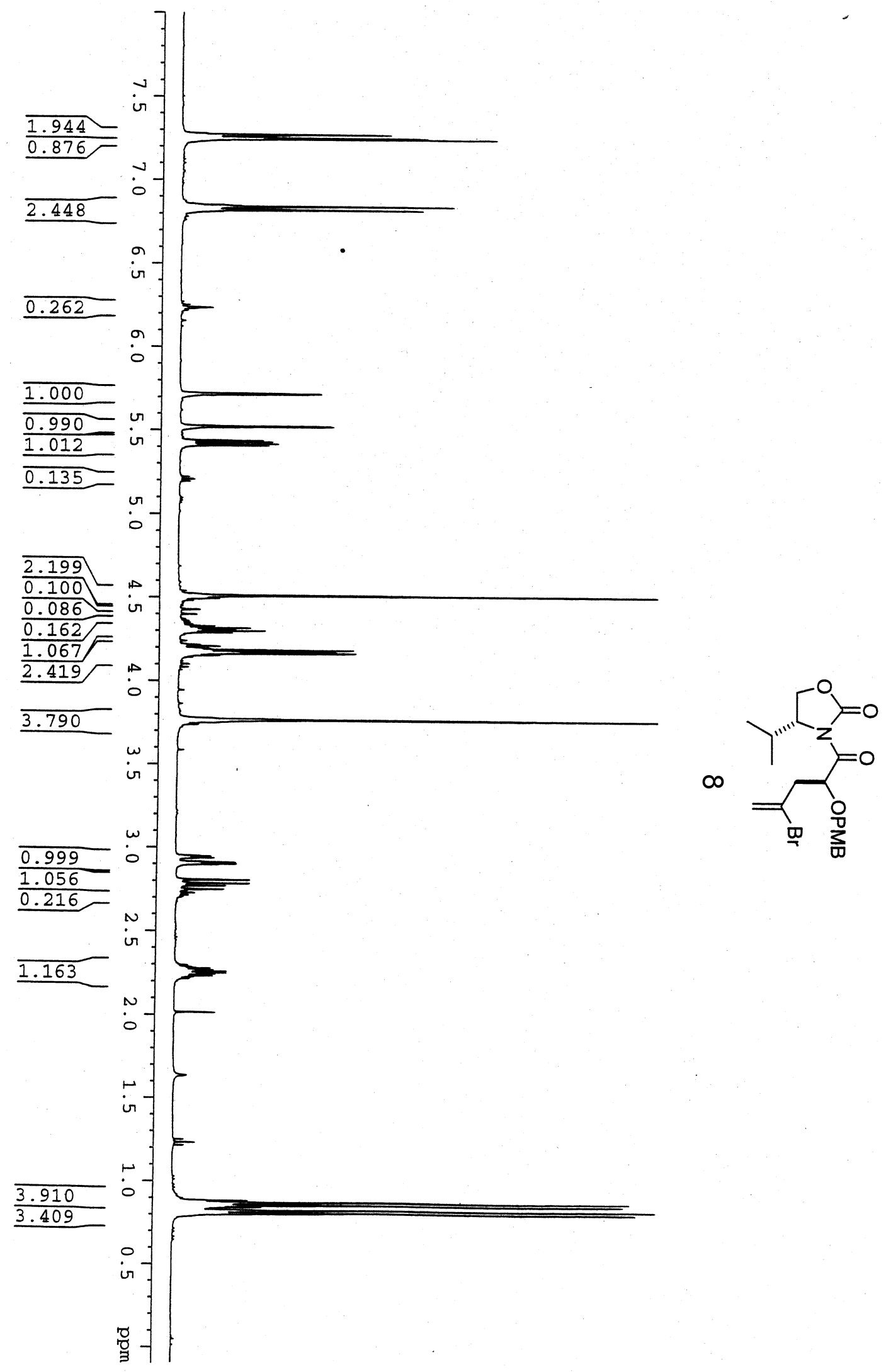




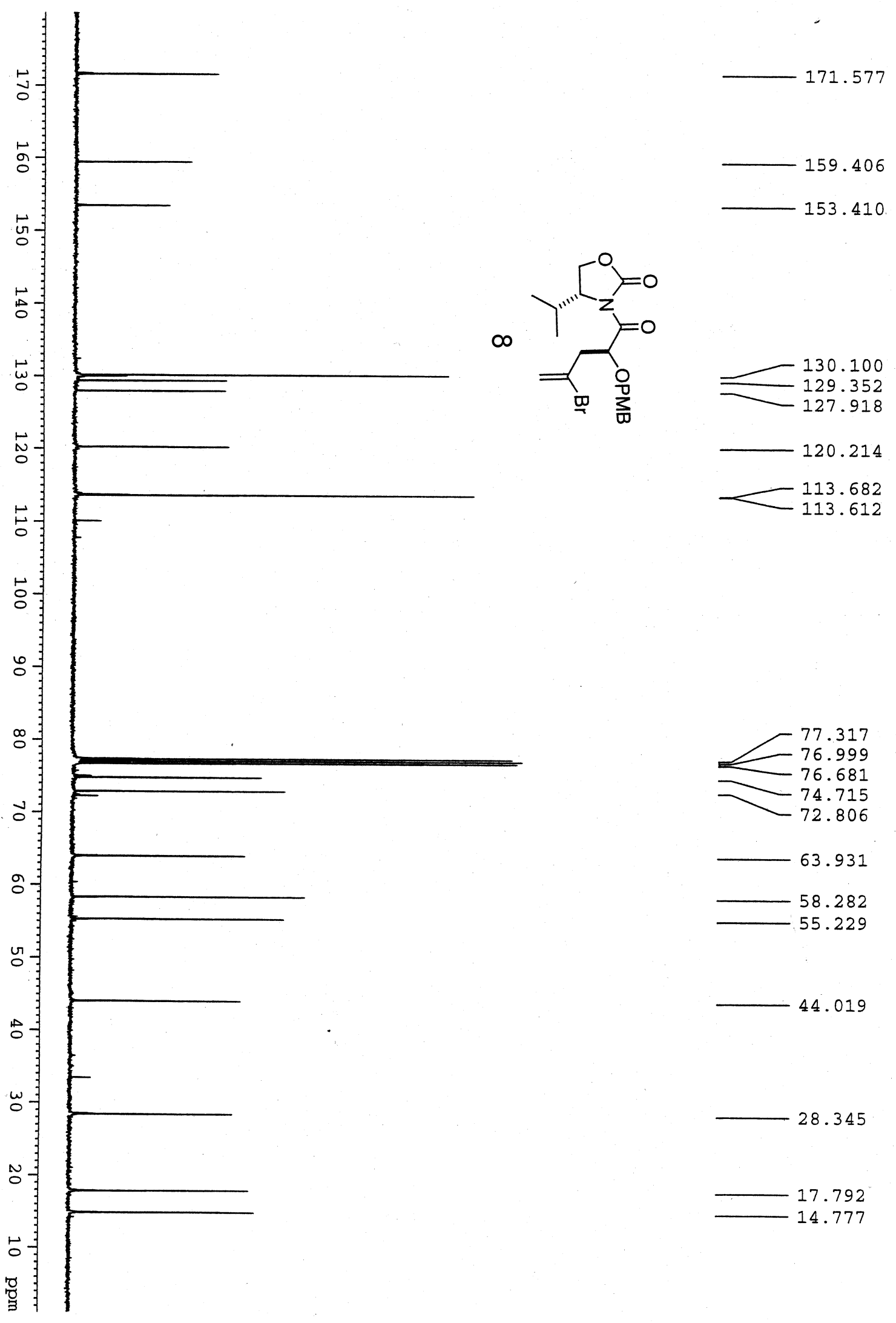



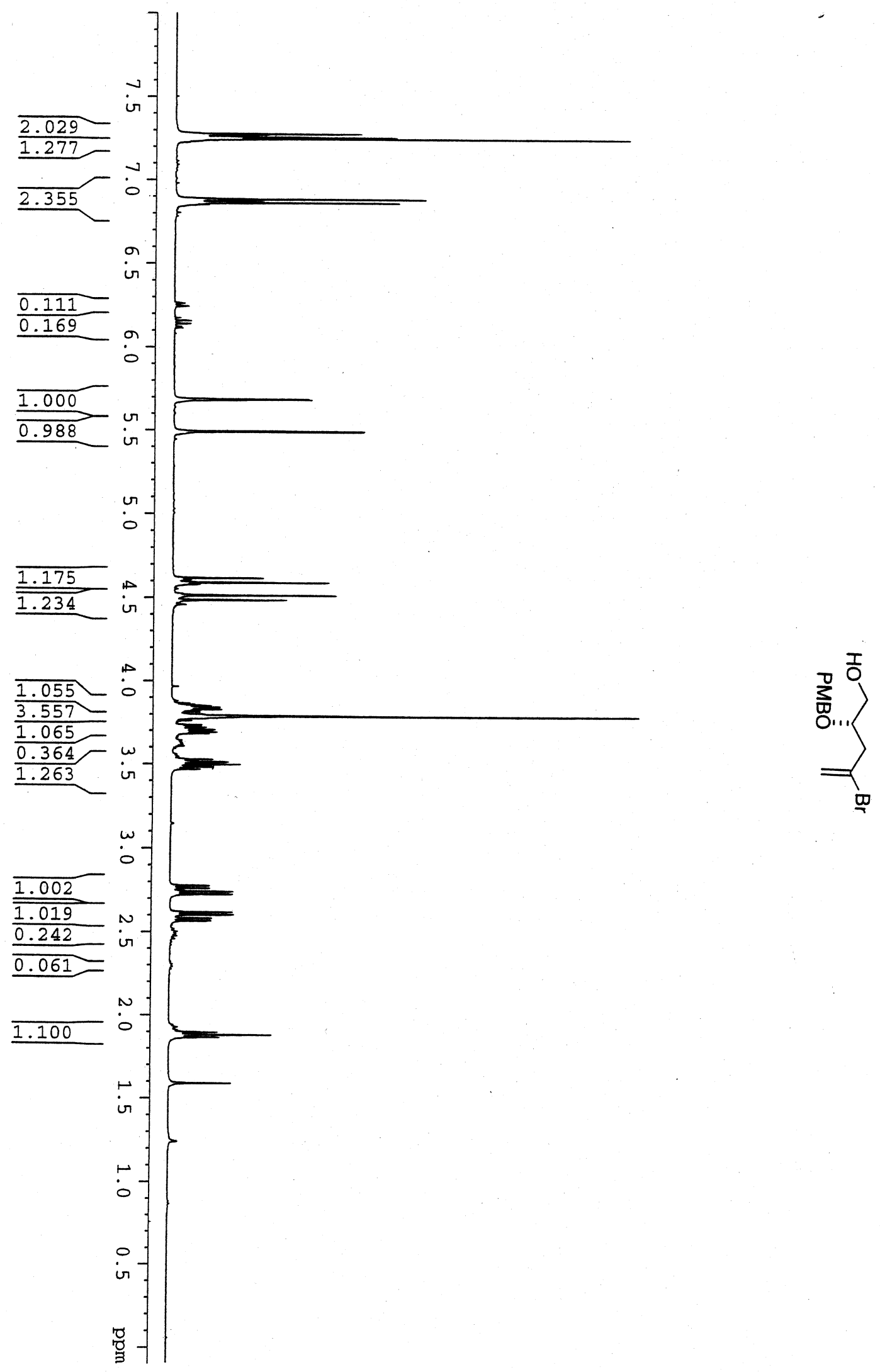


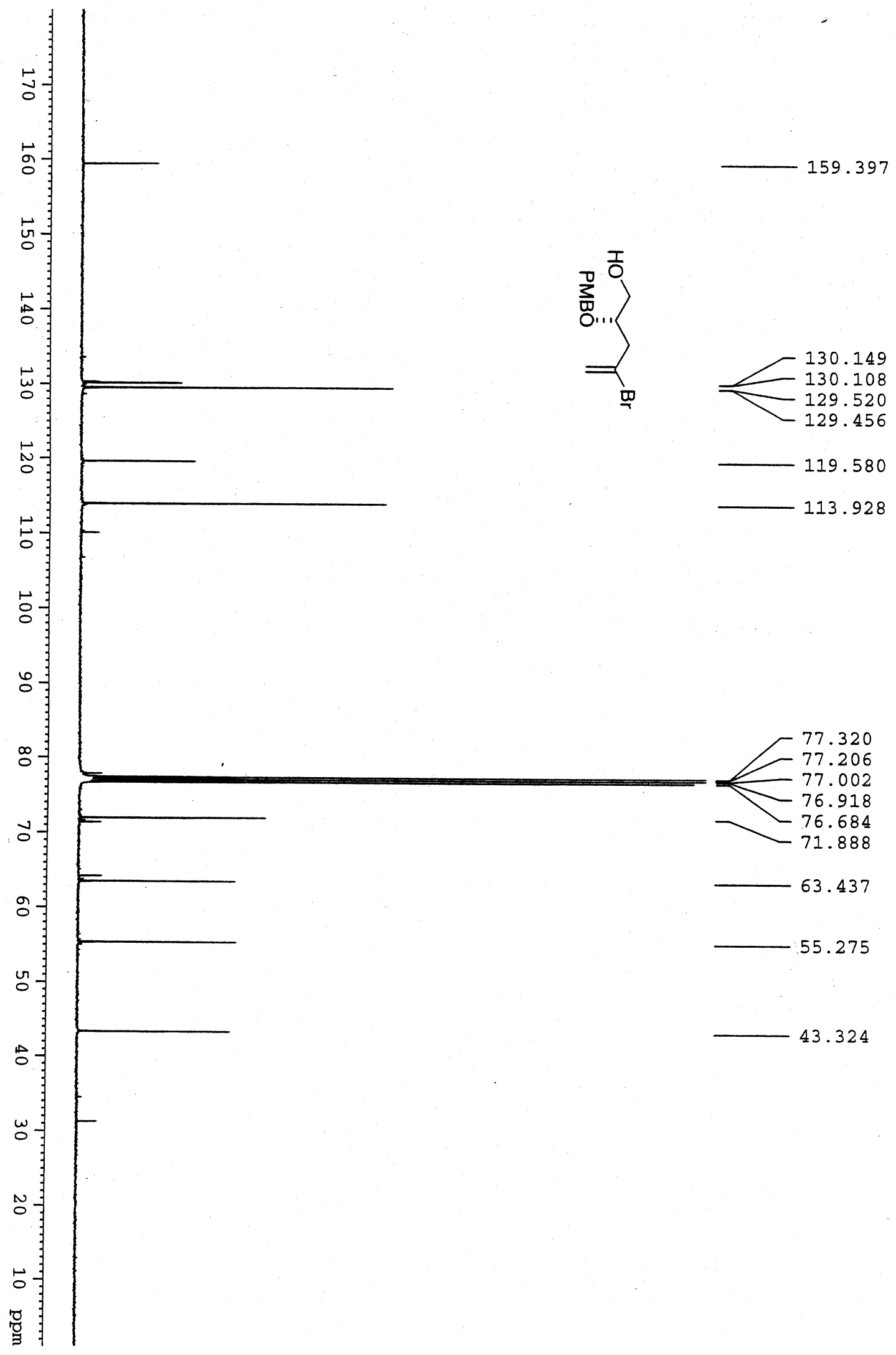




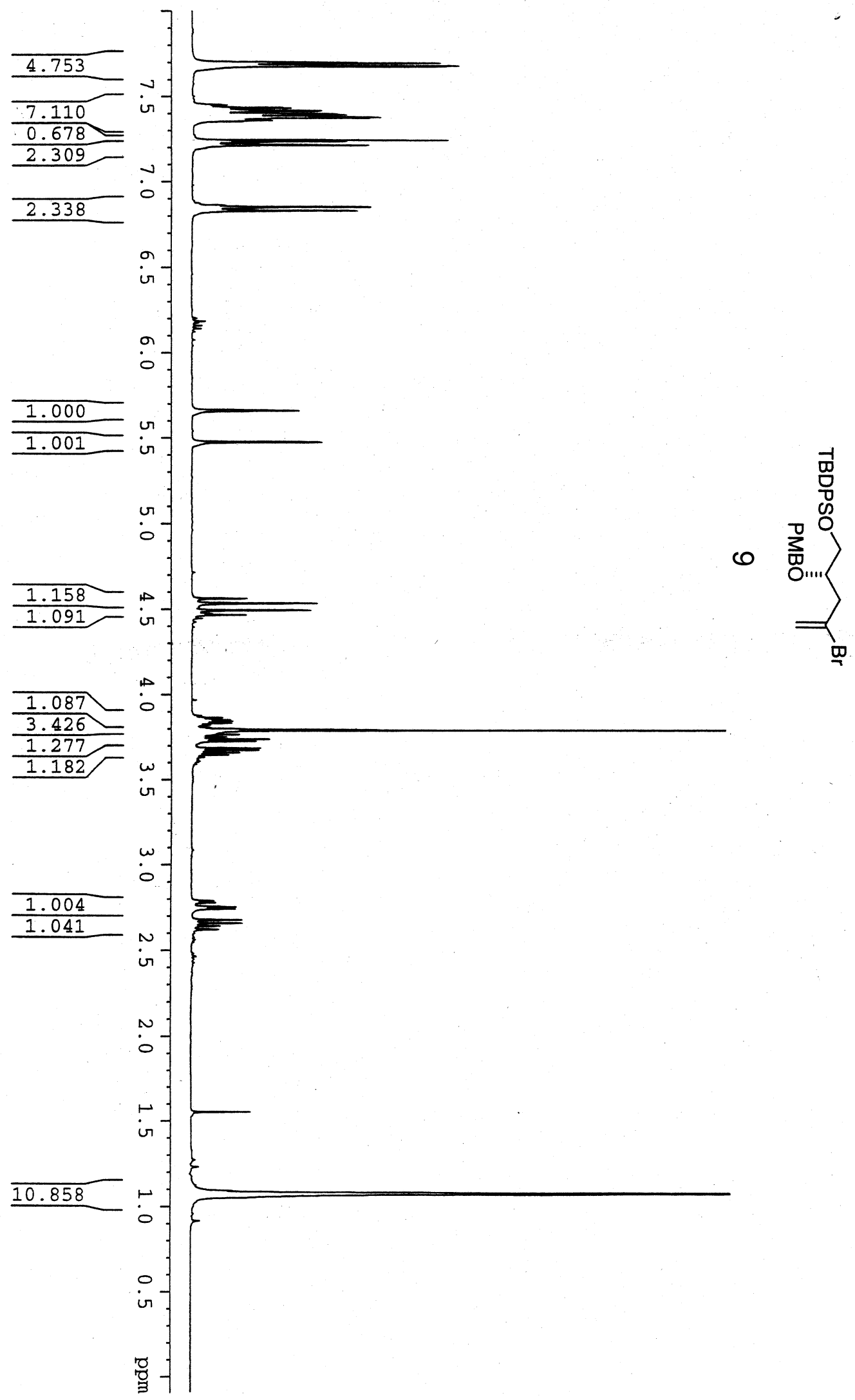




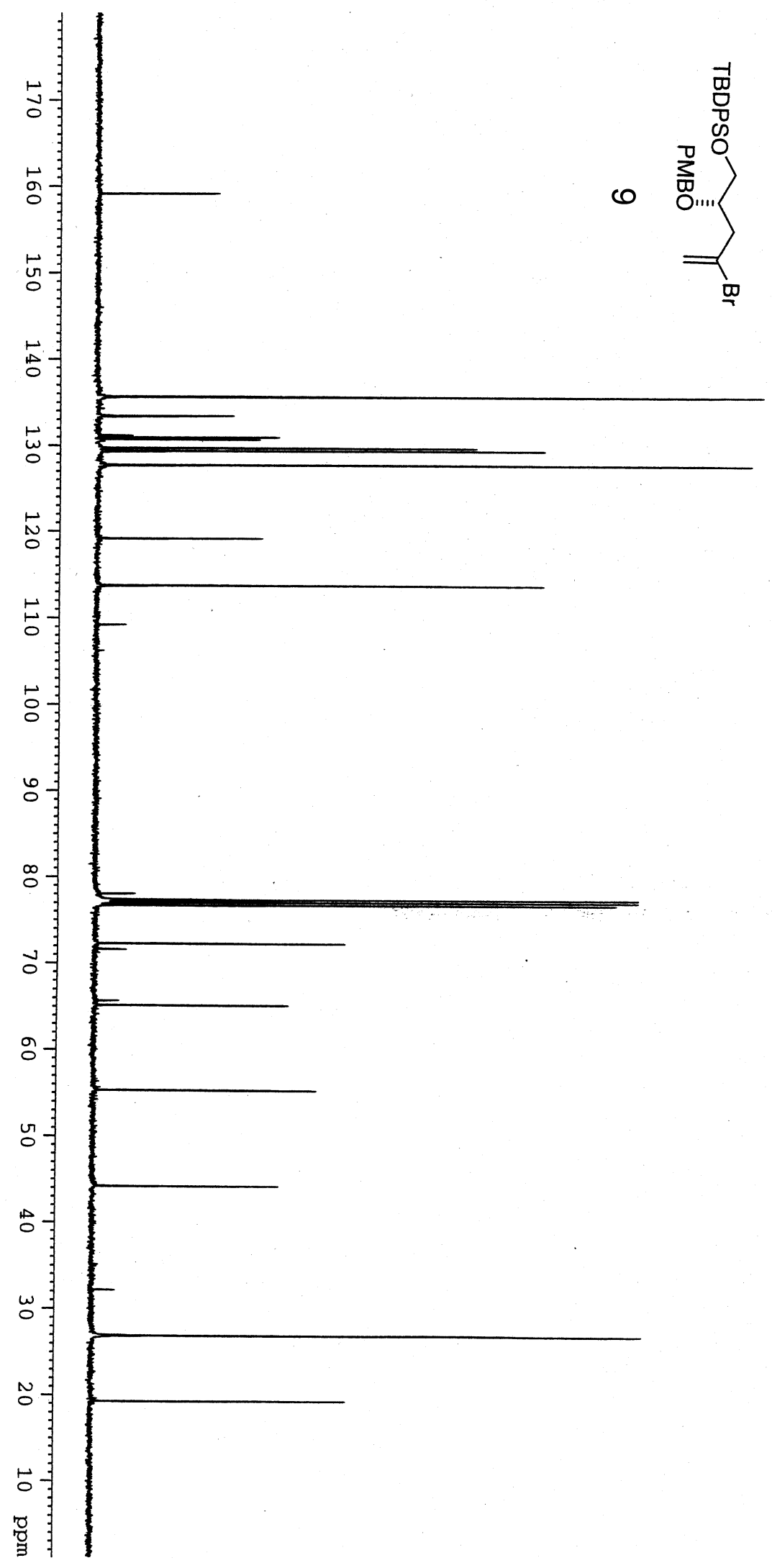

159.117
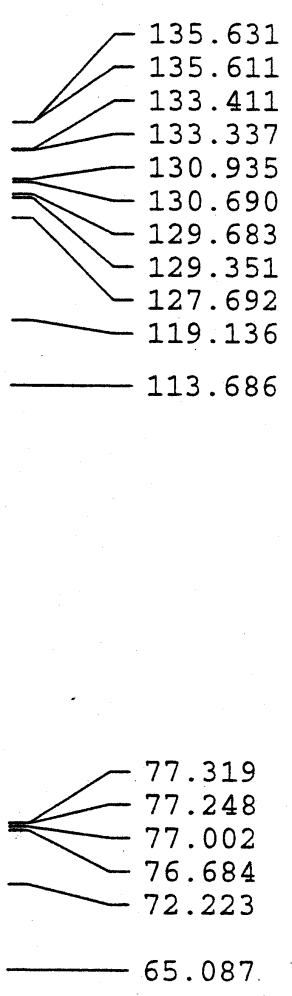

55.244

44.154

26.827

19.210 


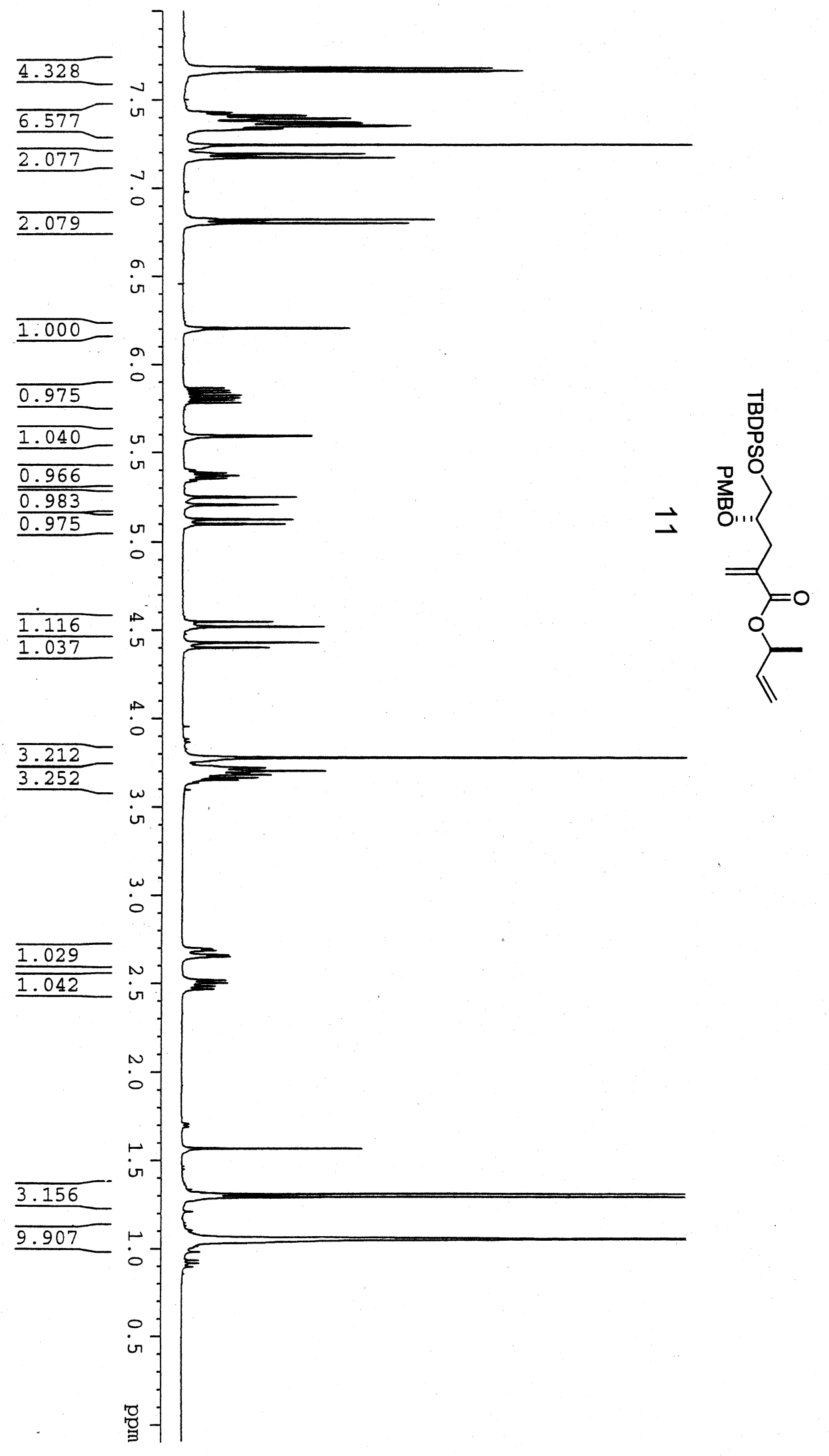




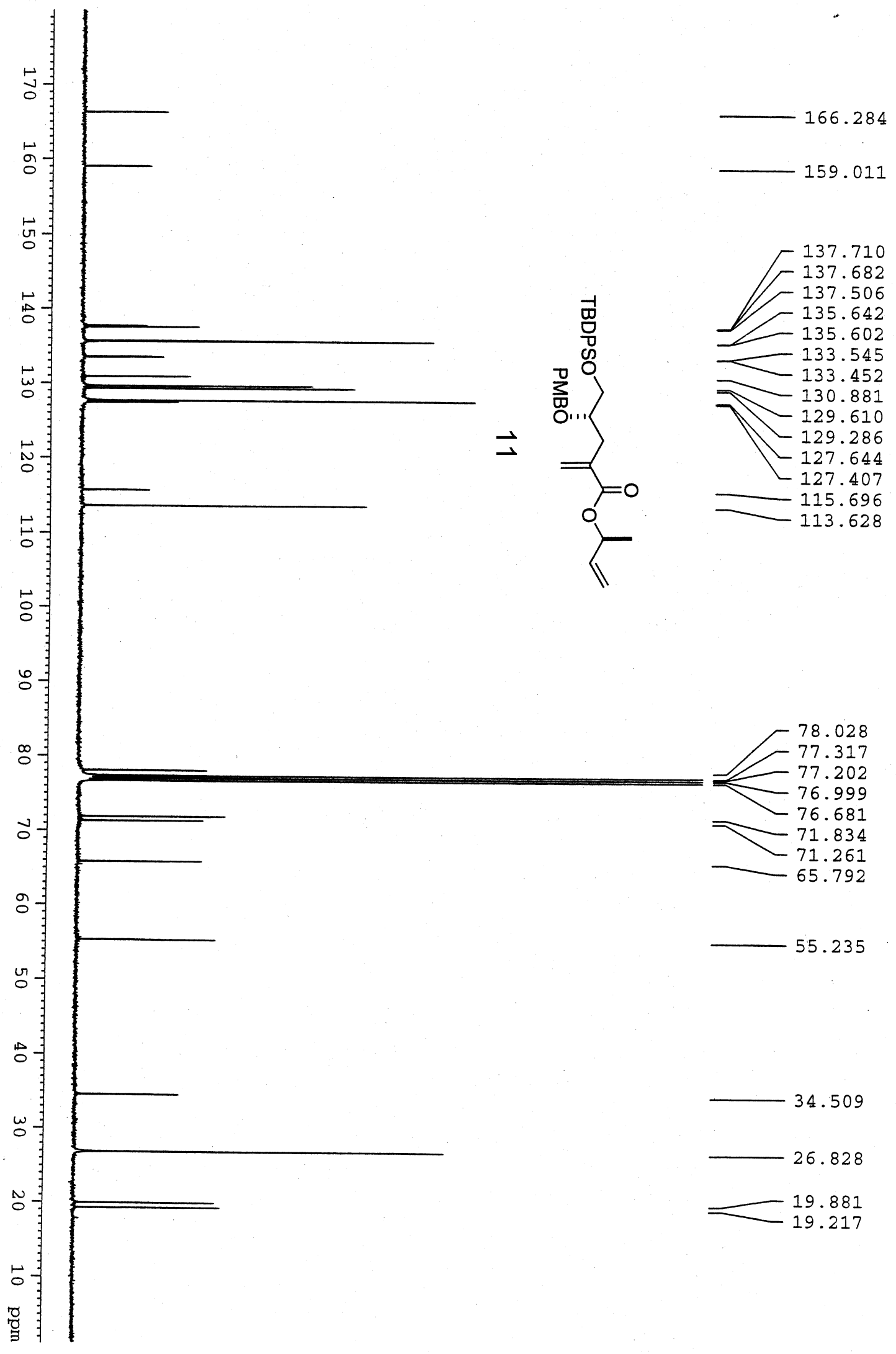




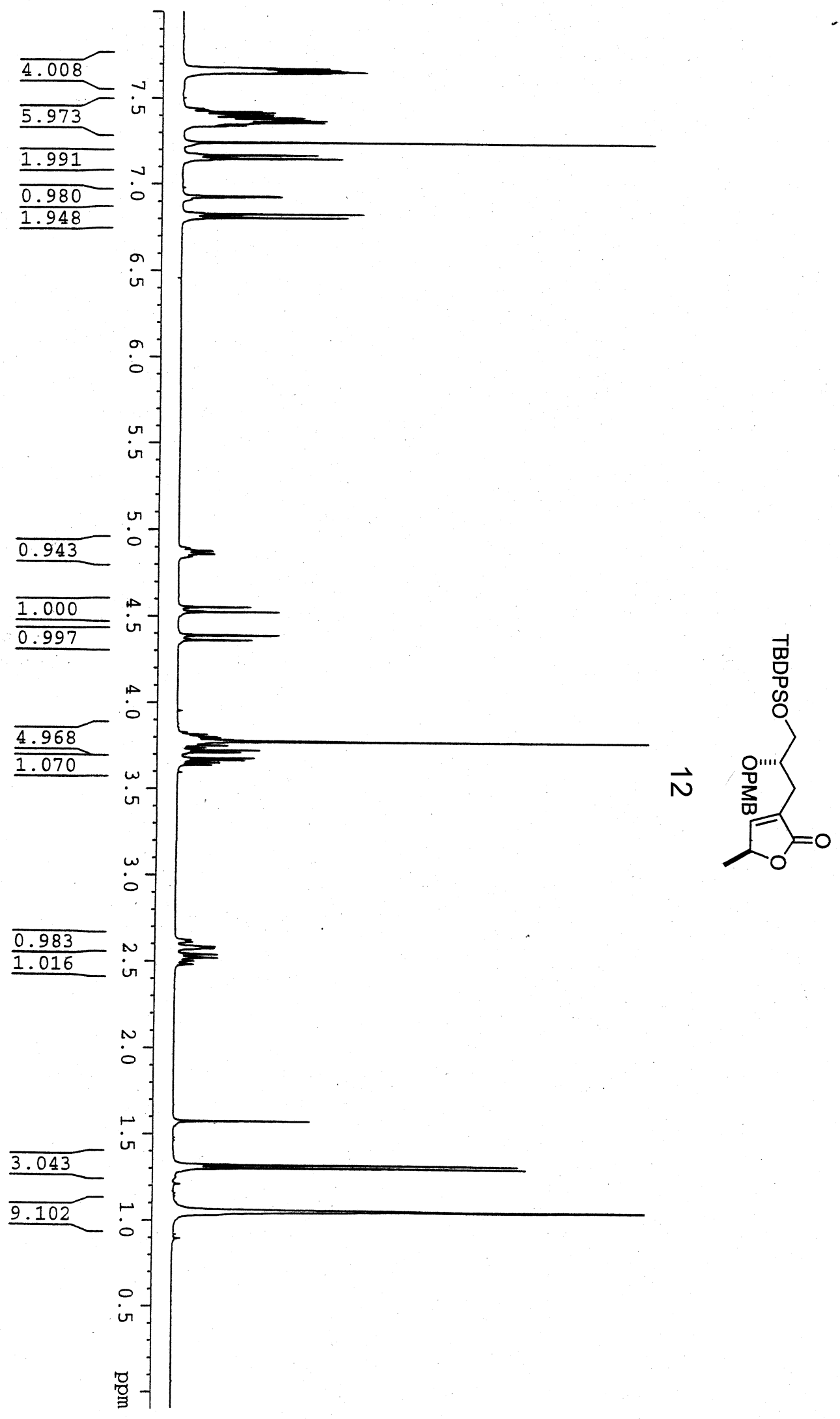




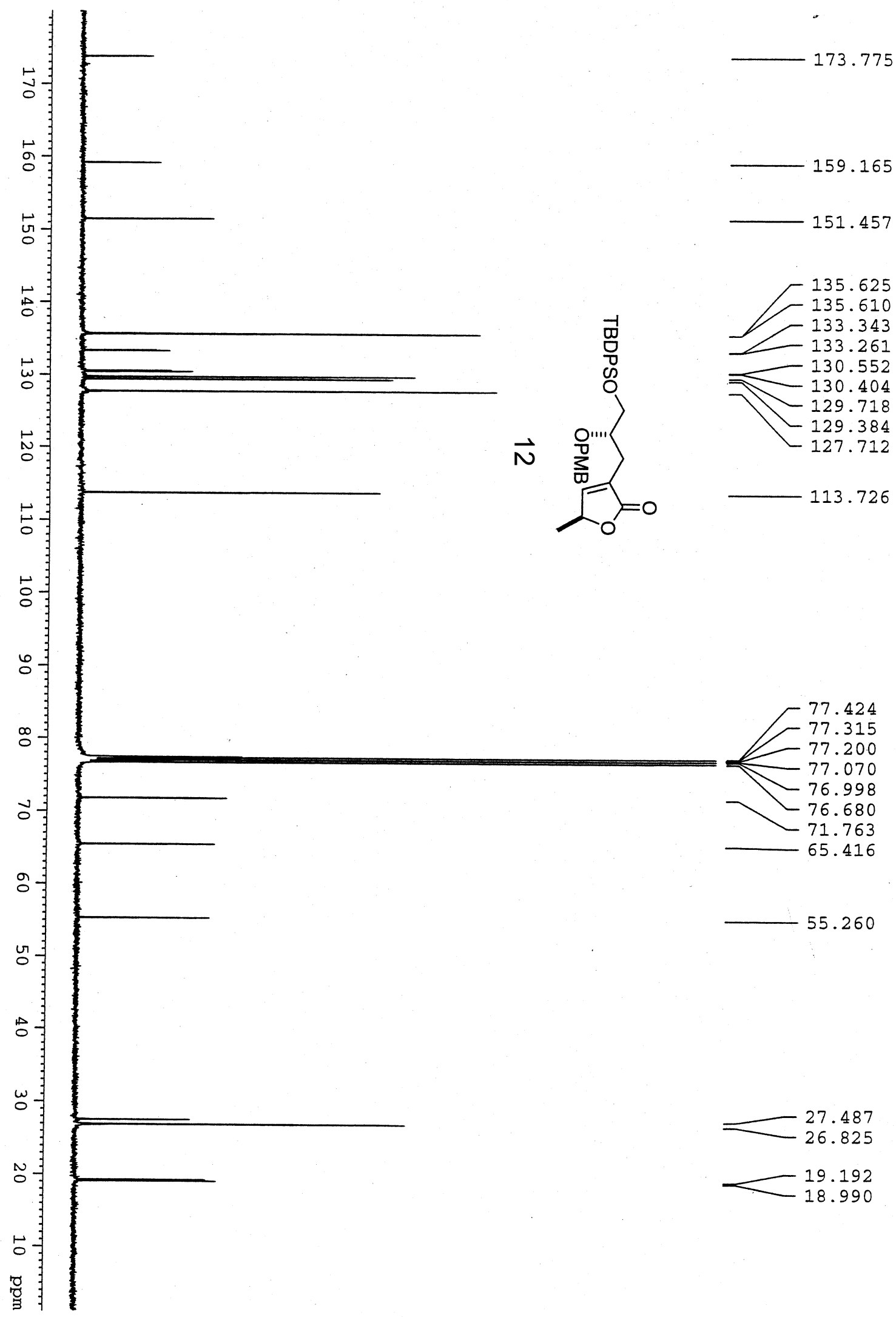



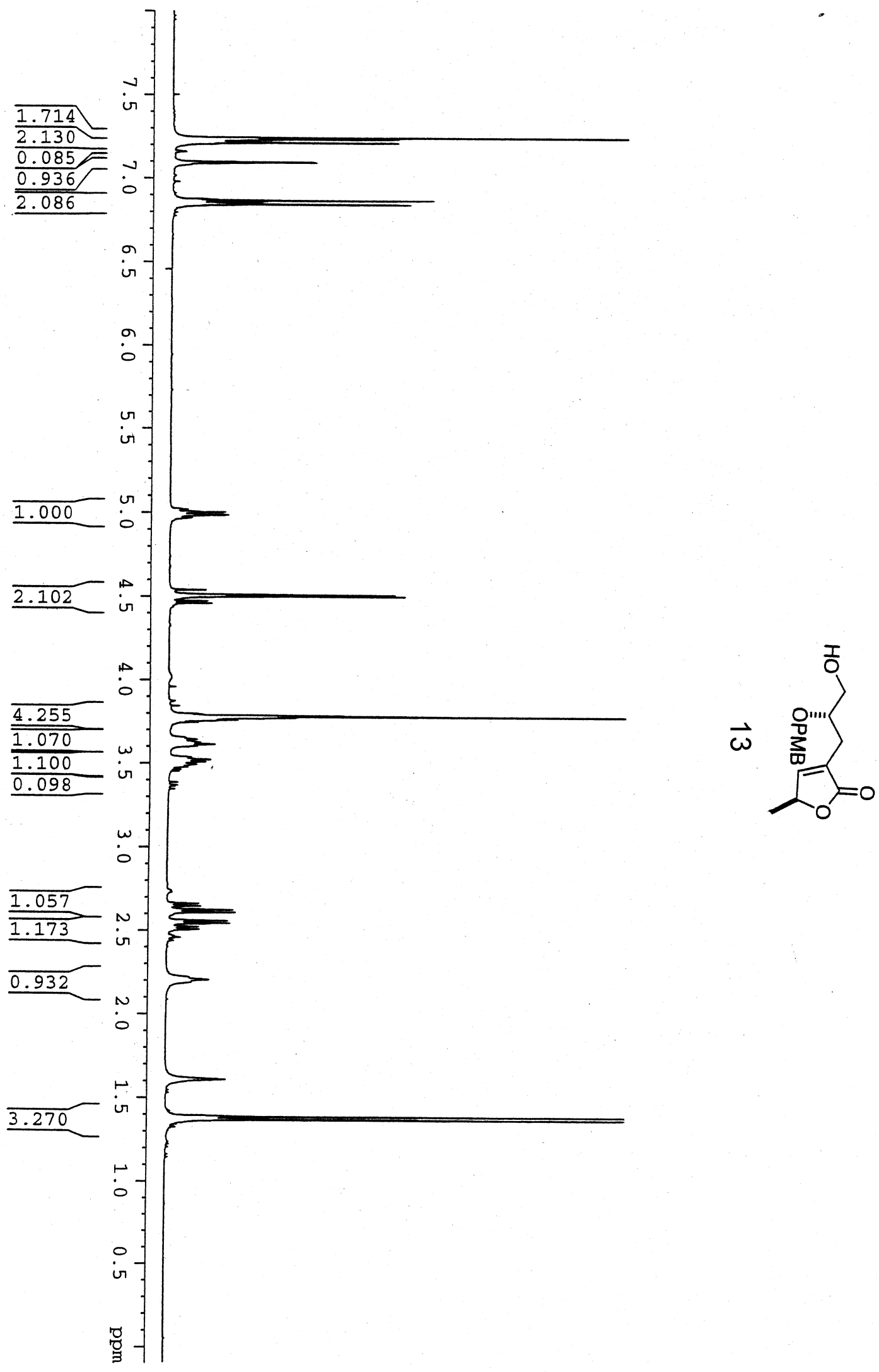


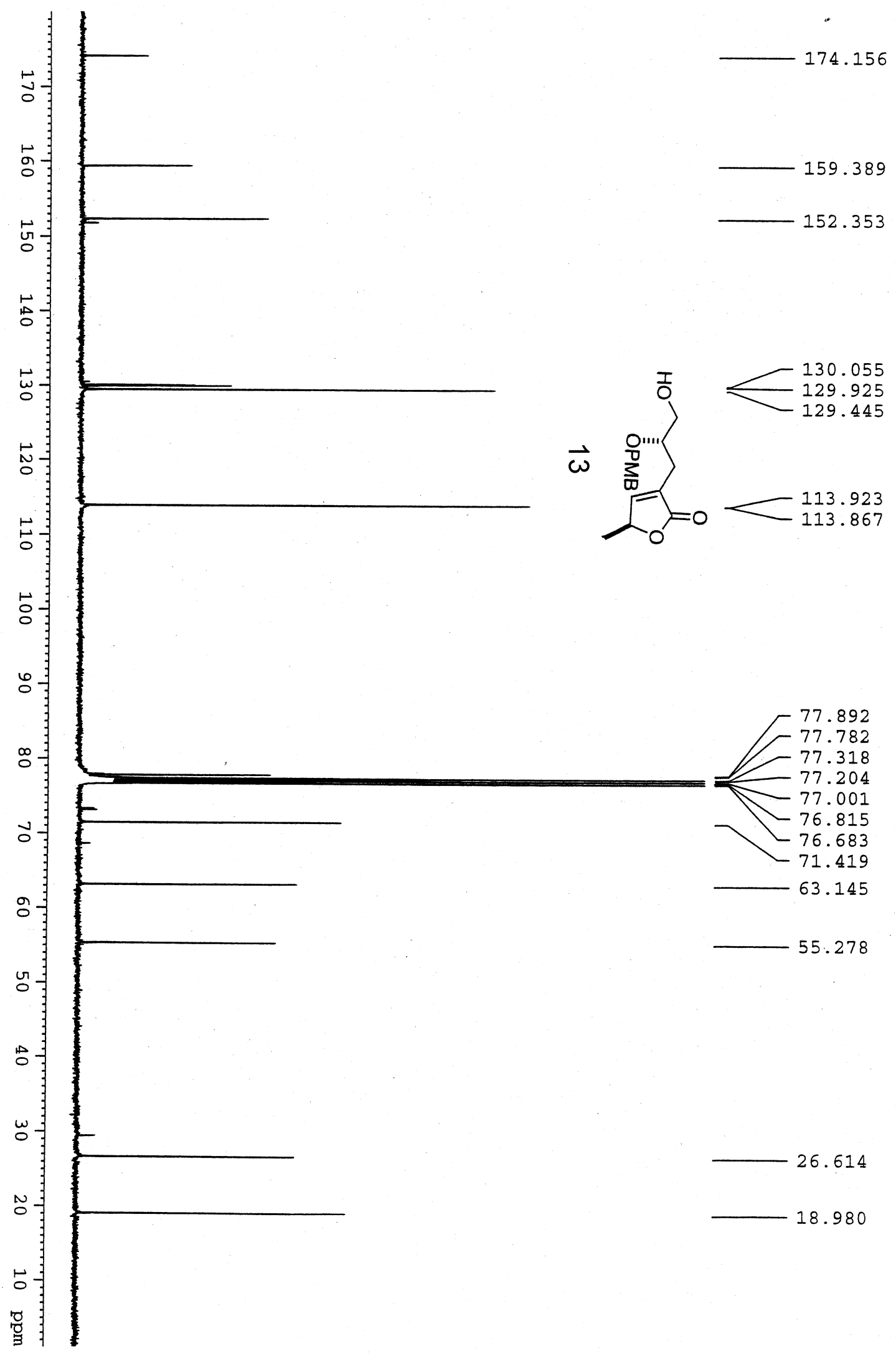




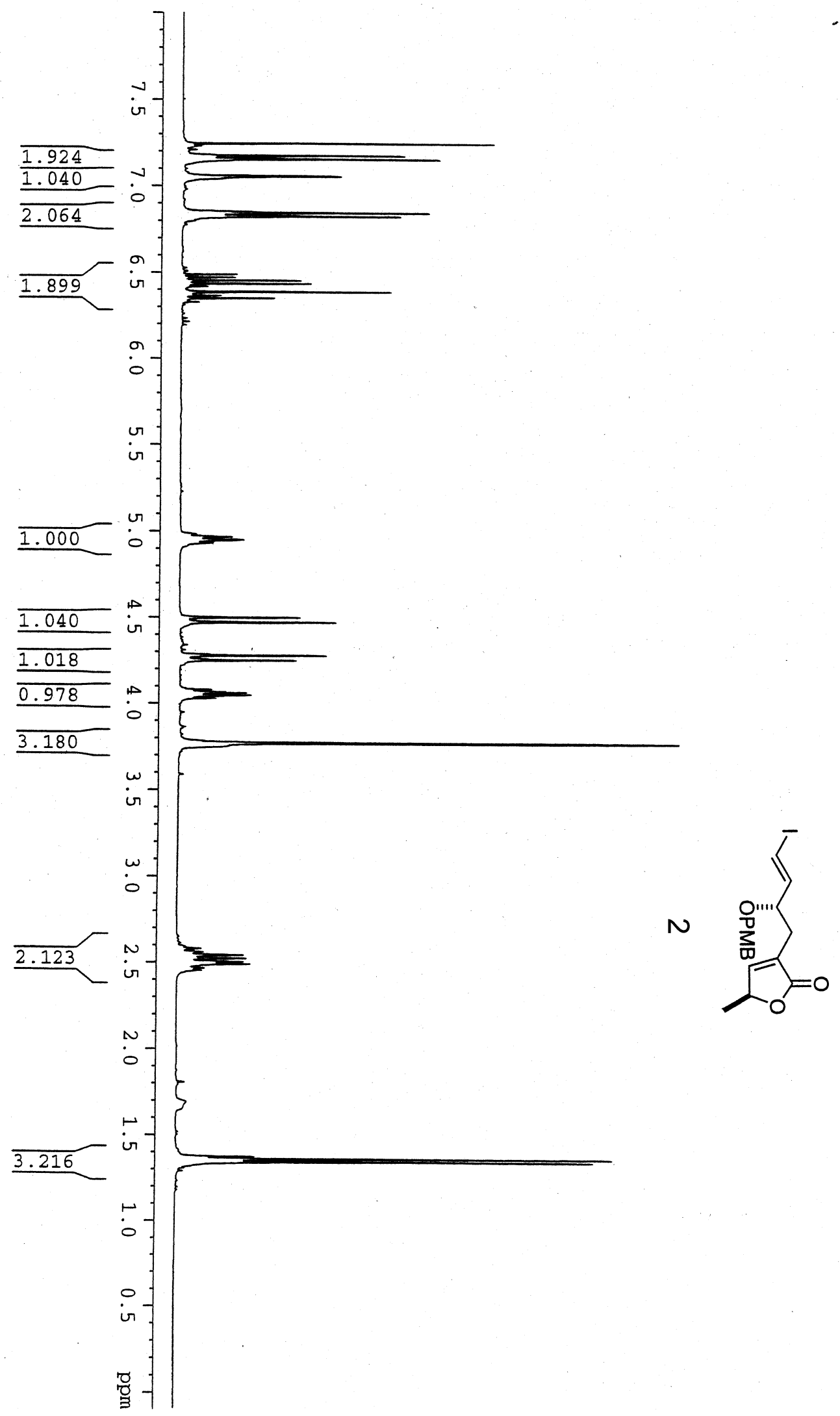




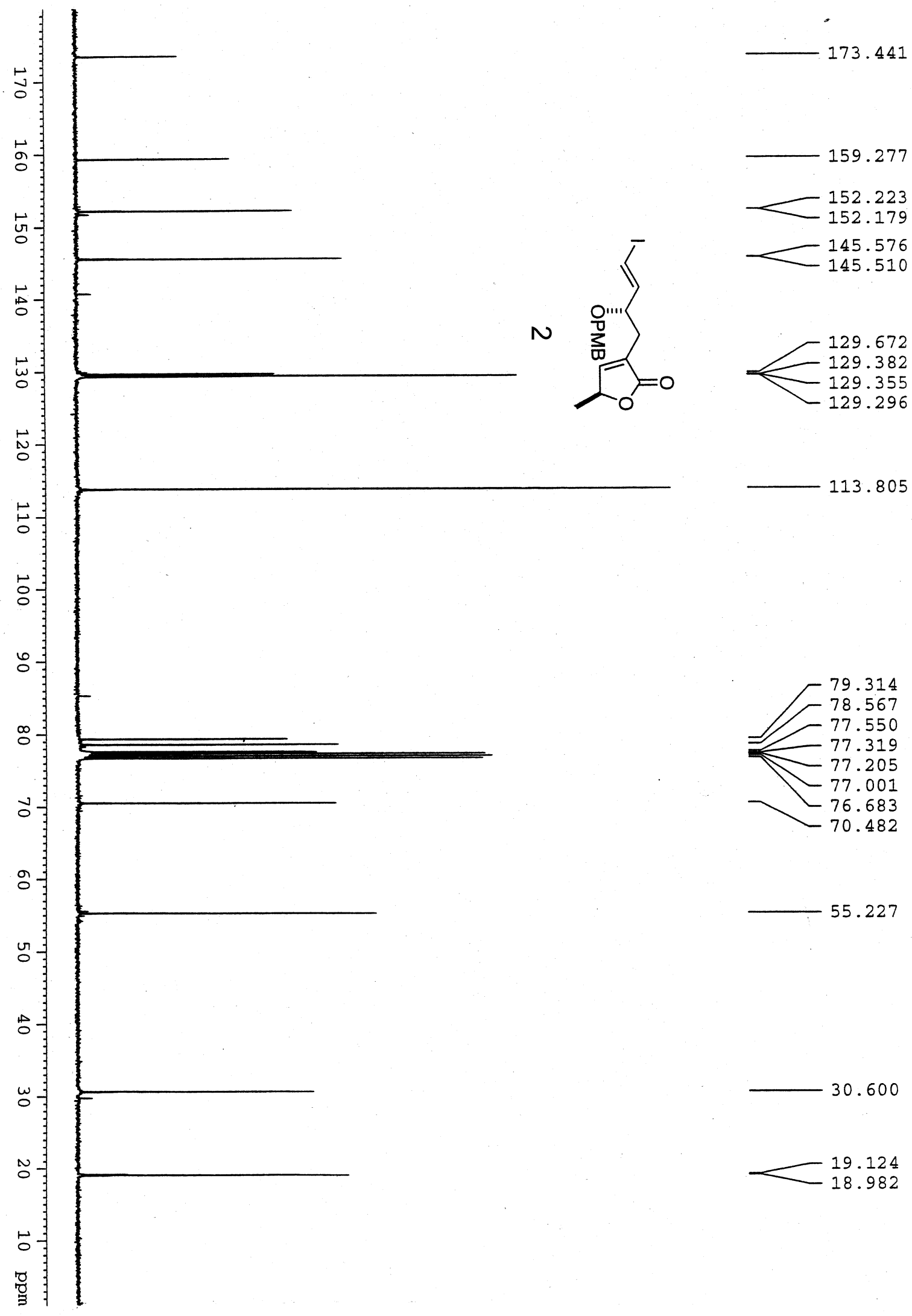




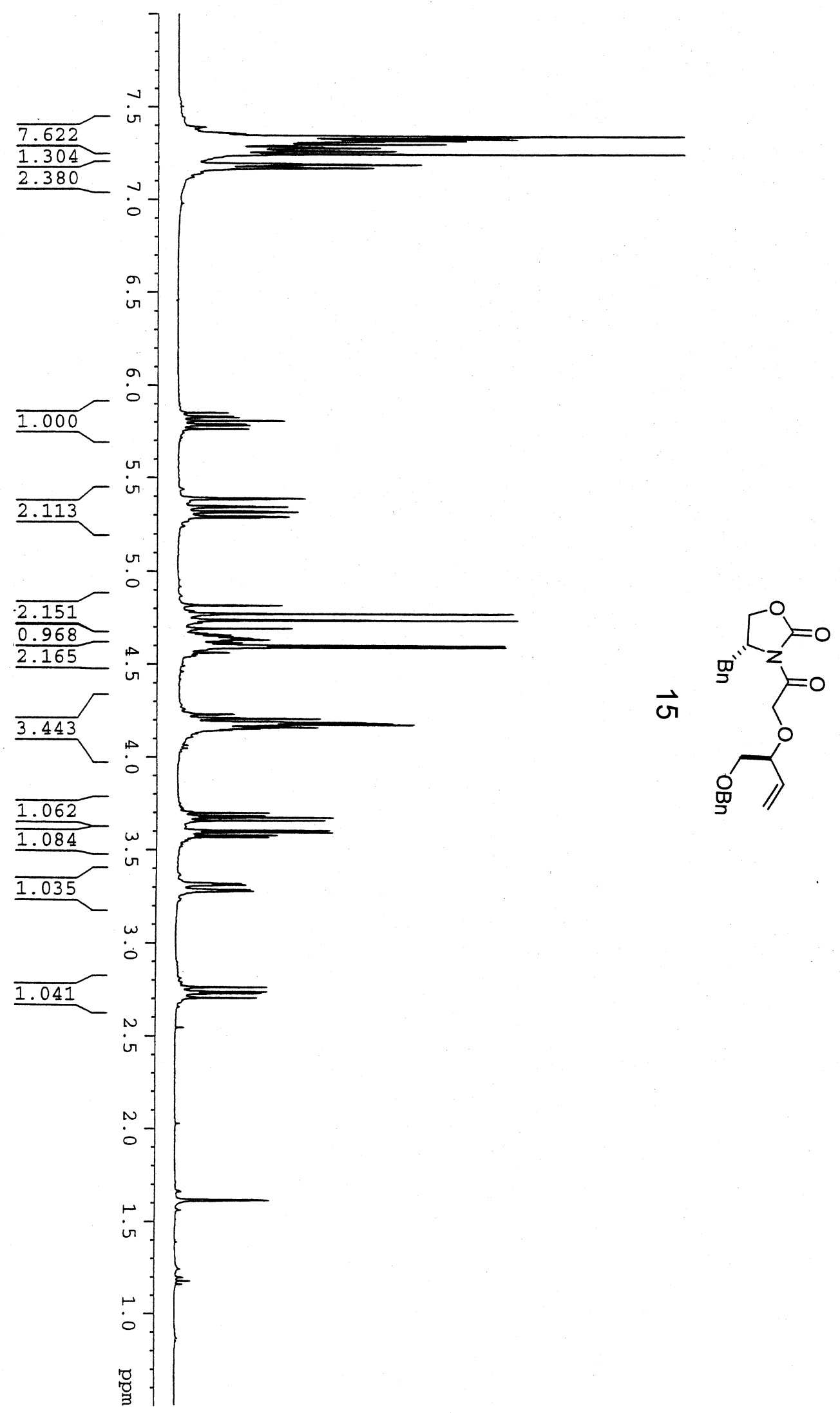




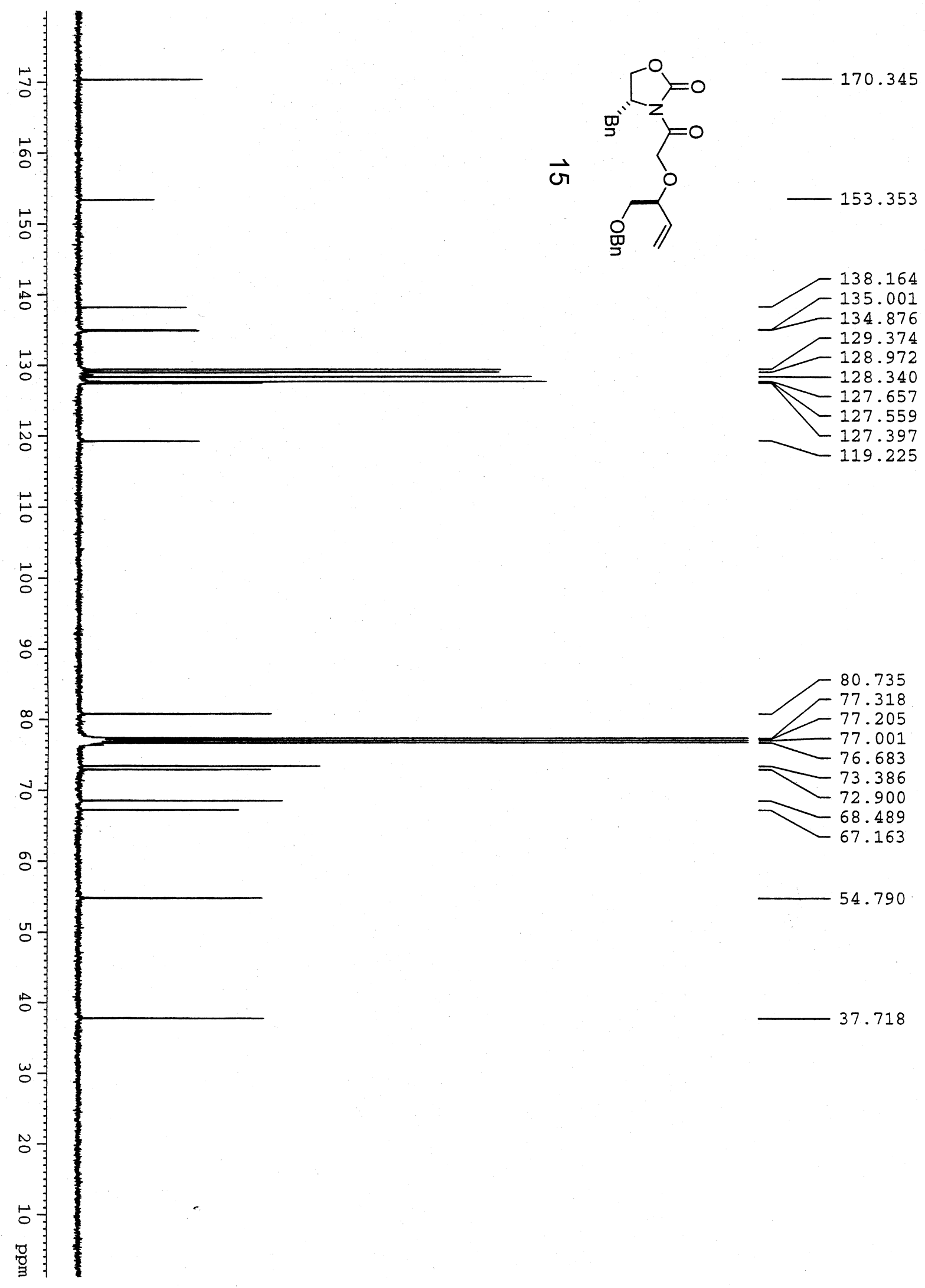




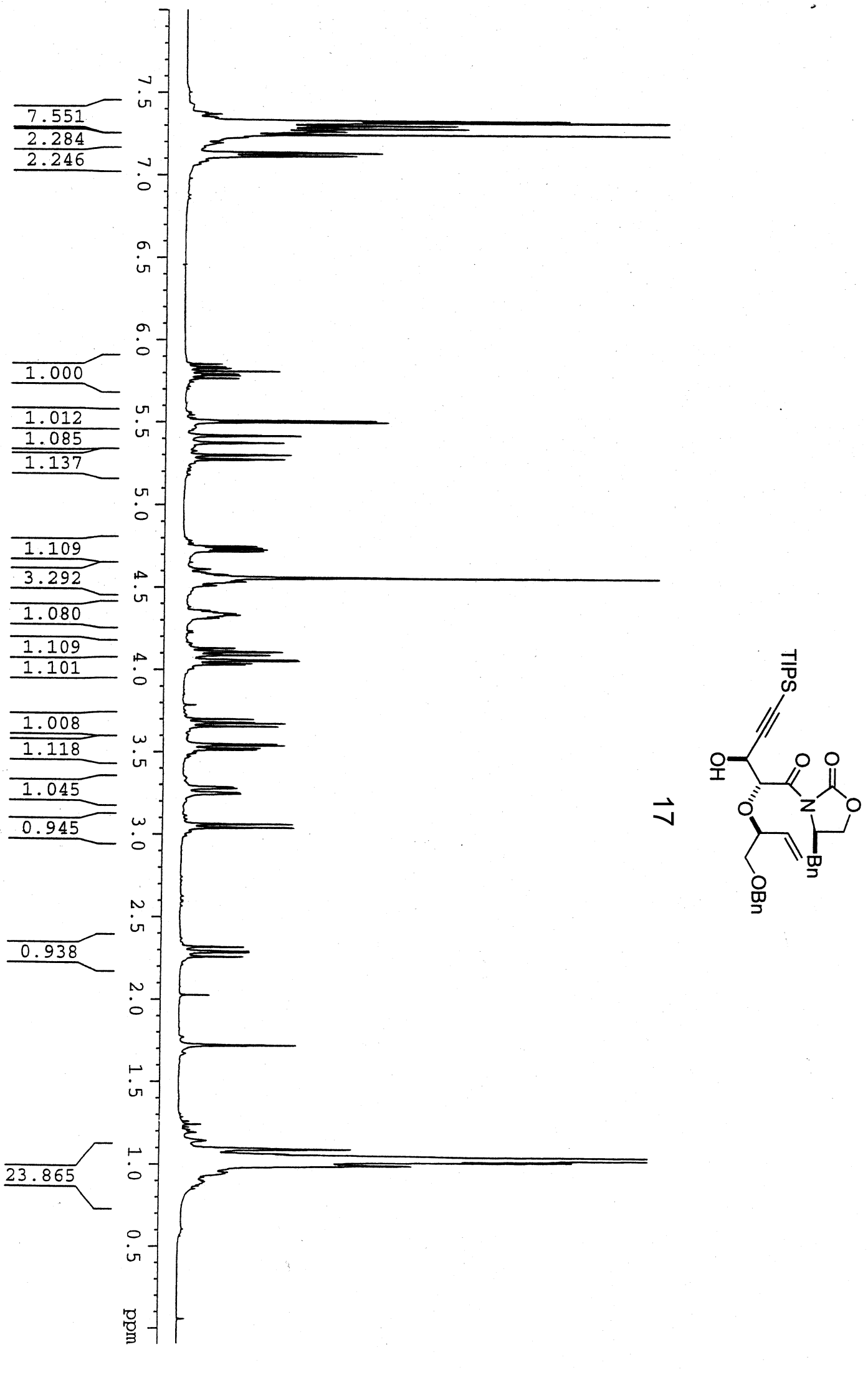




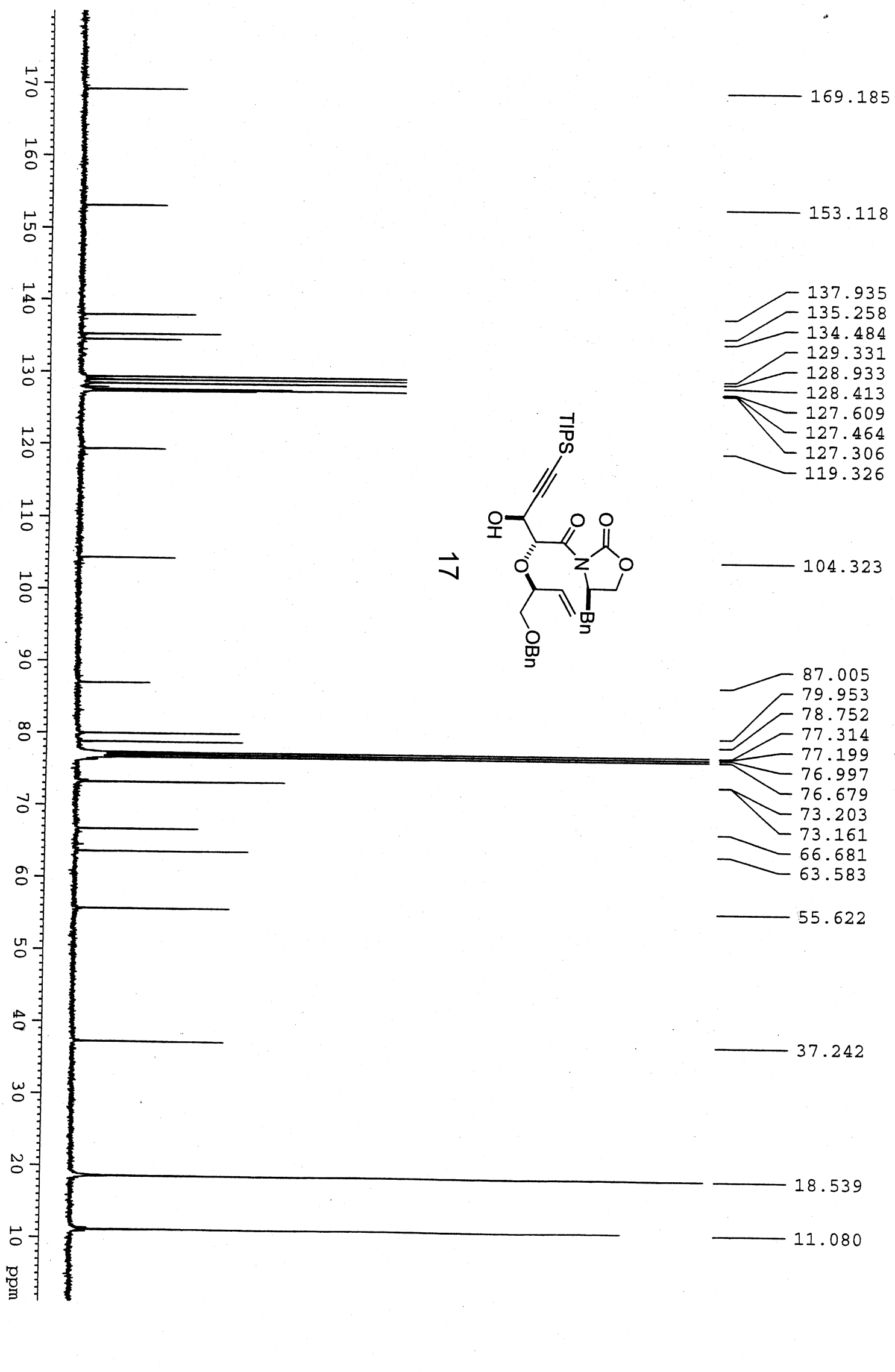



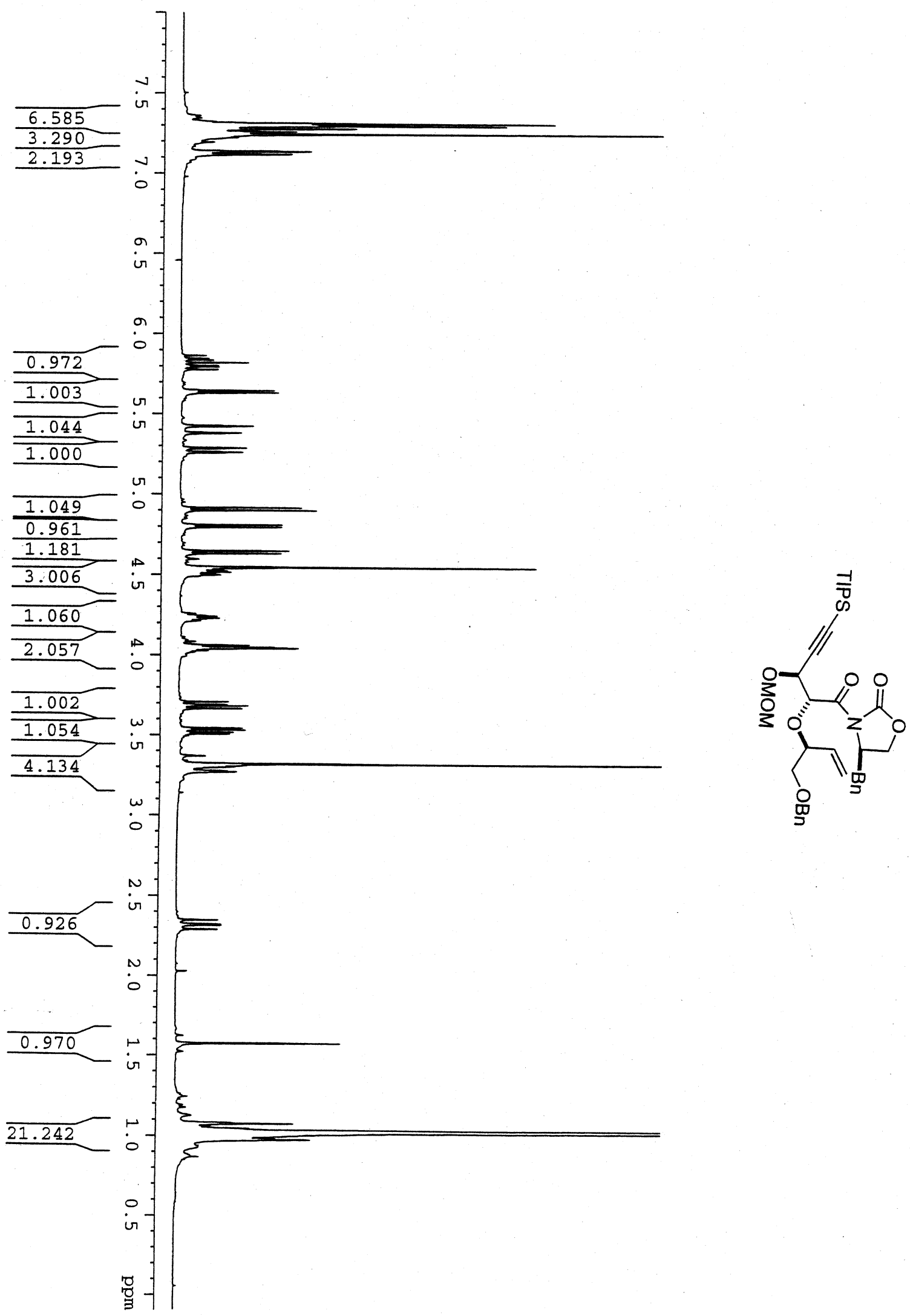


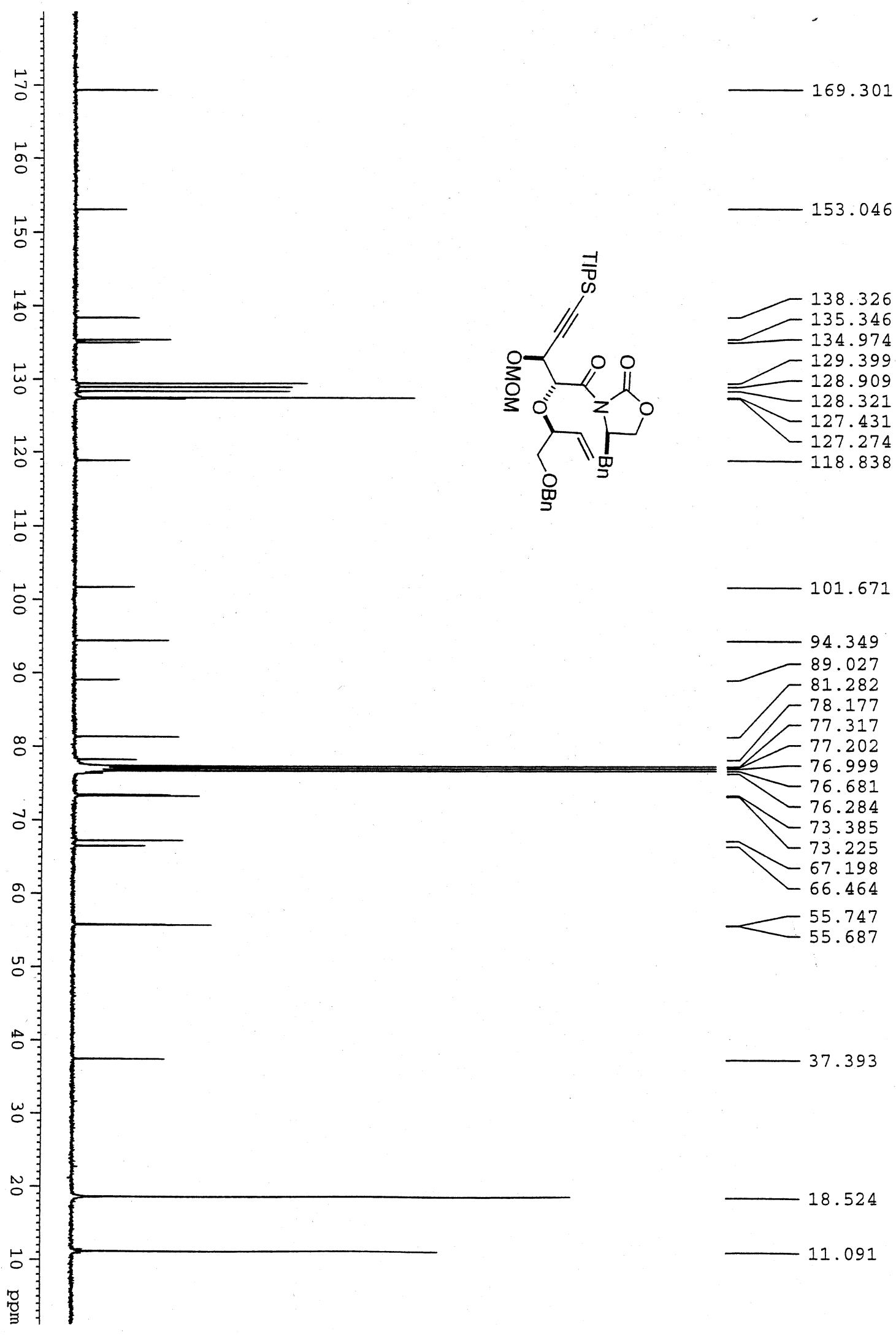




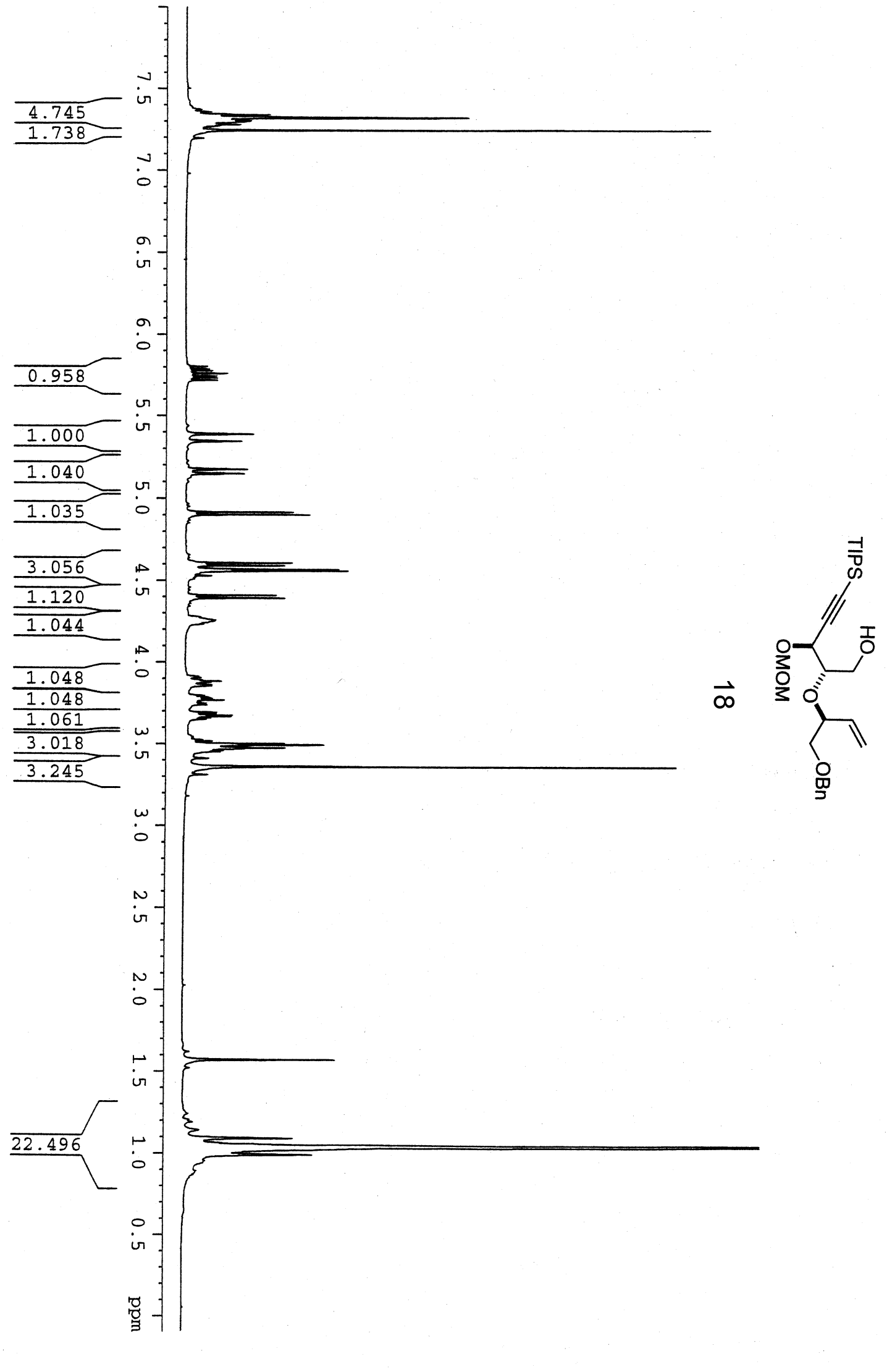




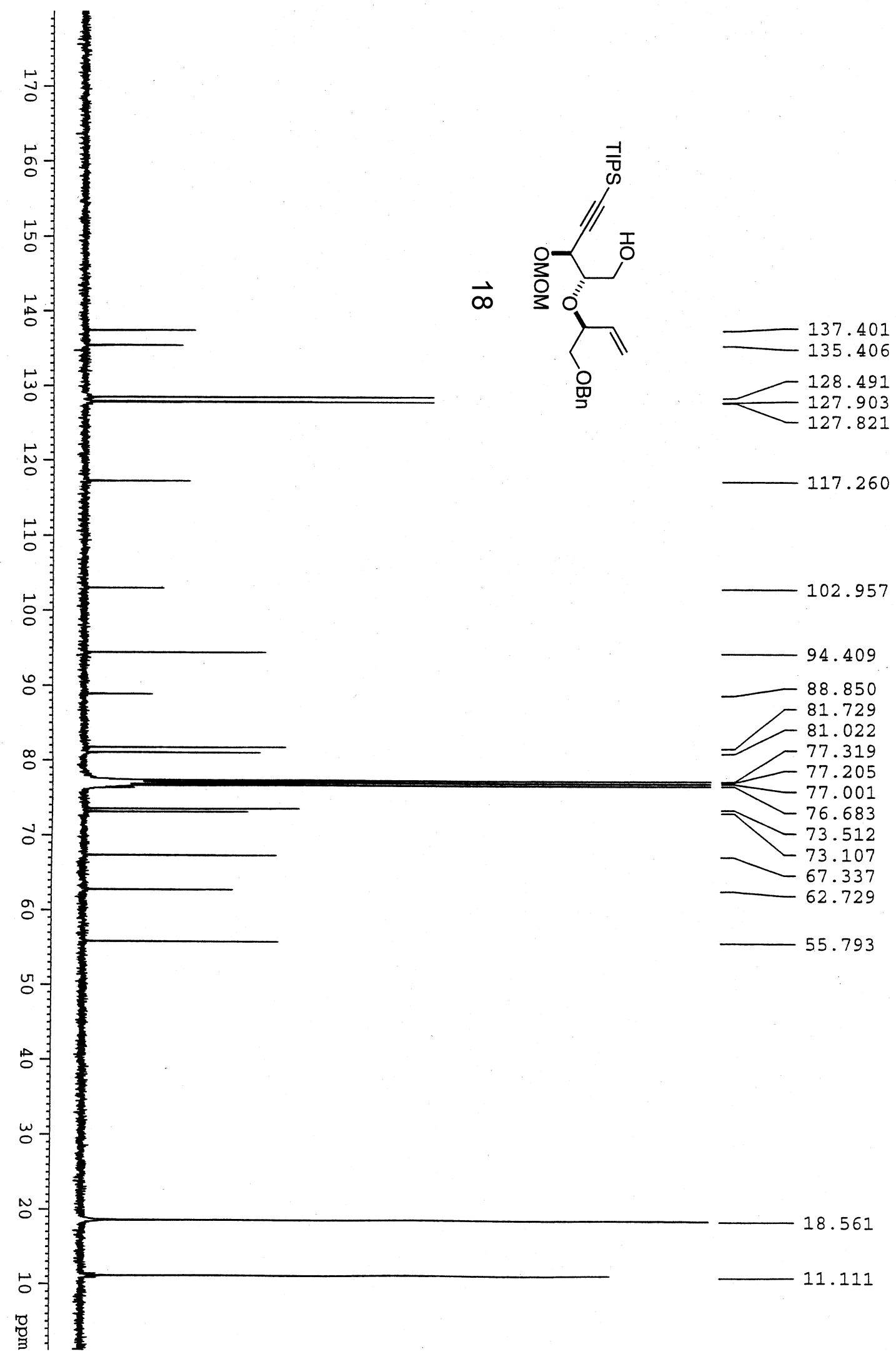




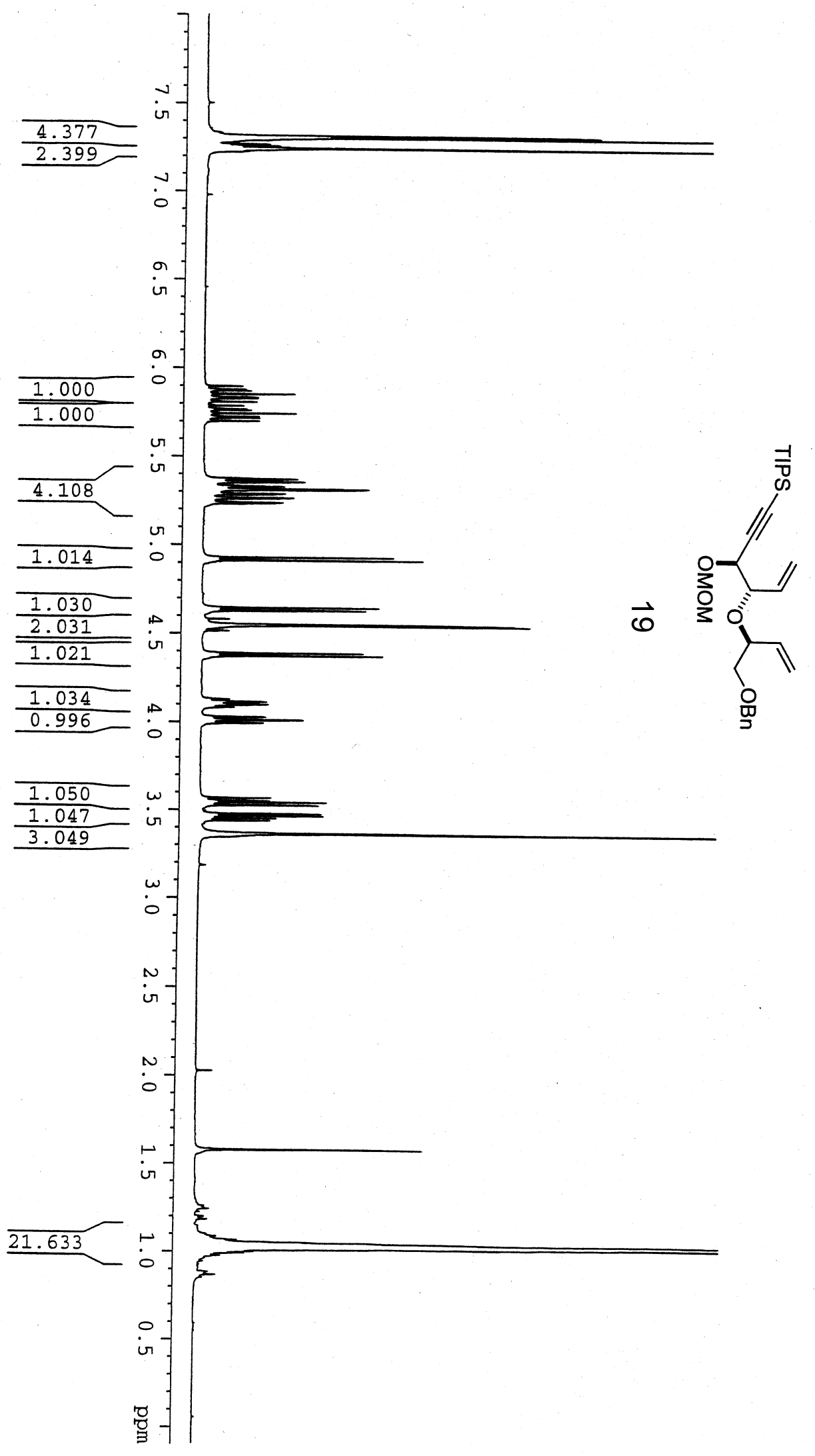




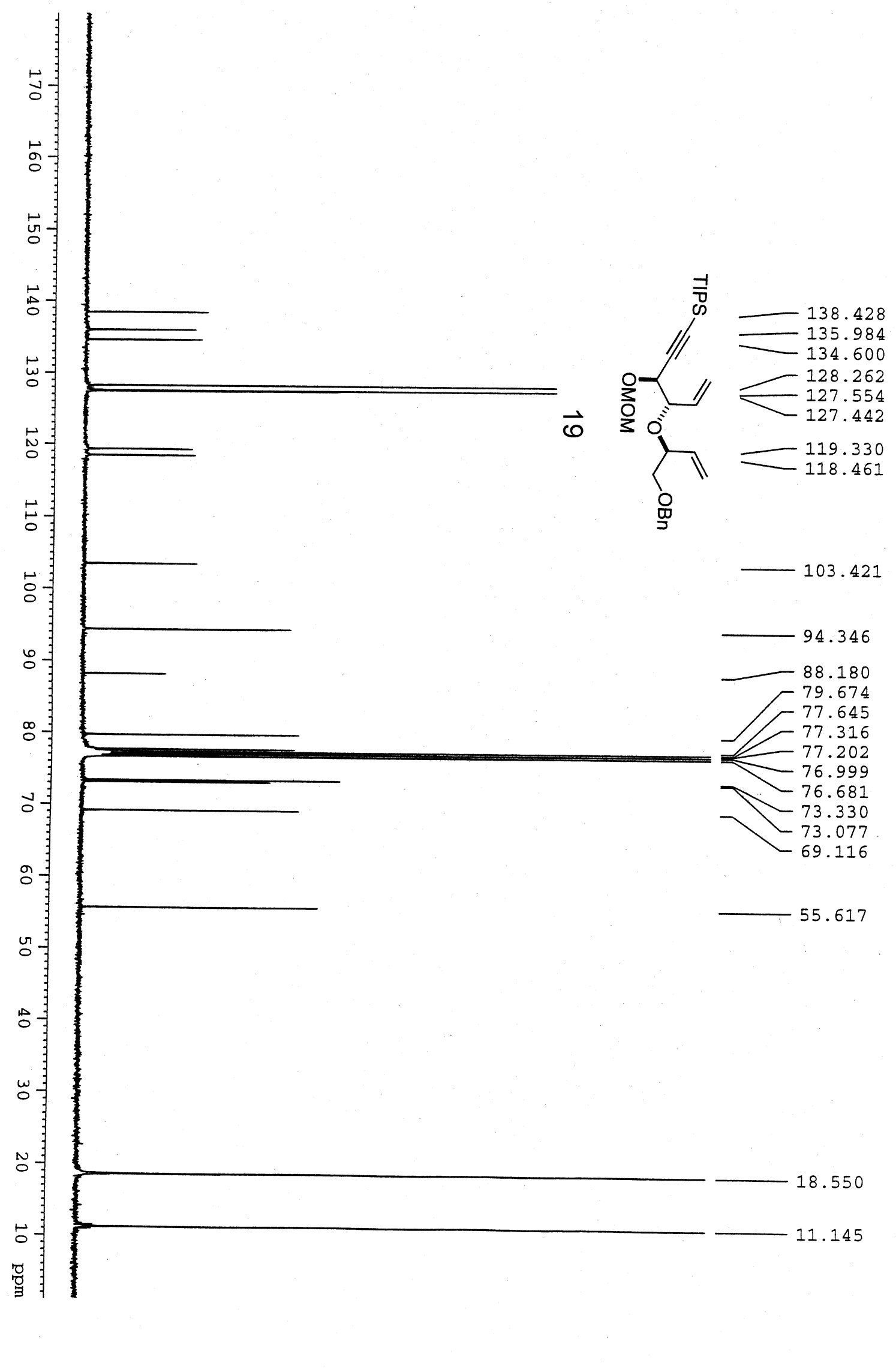




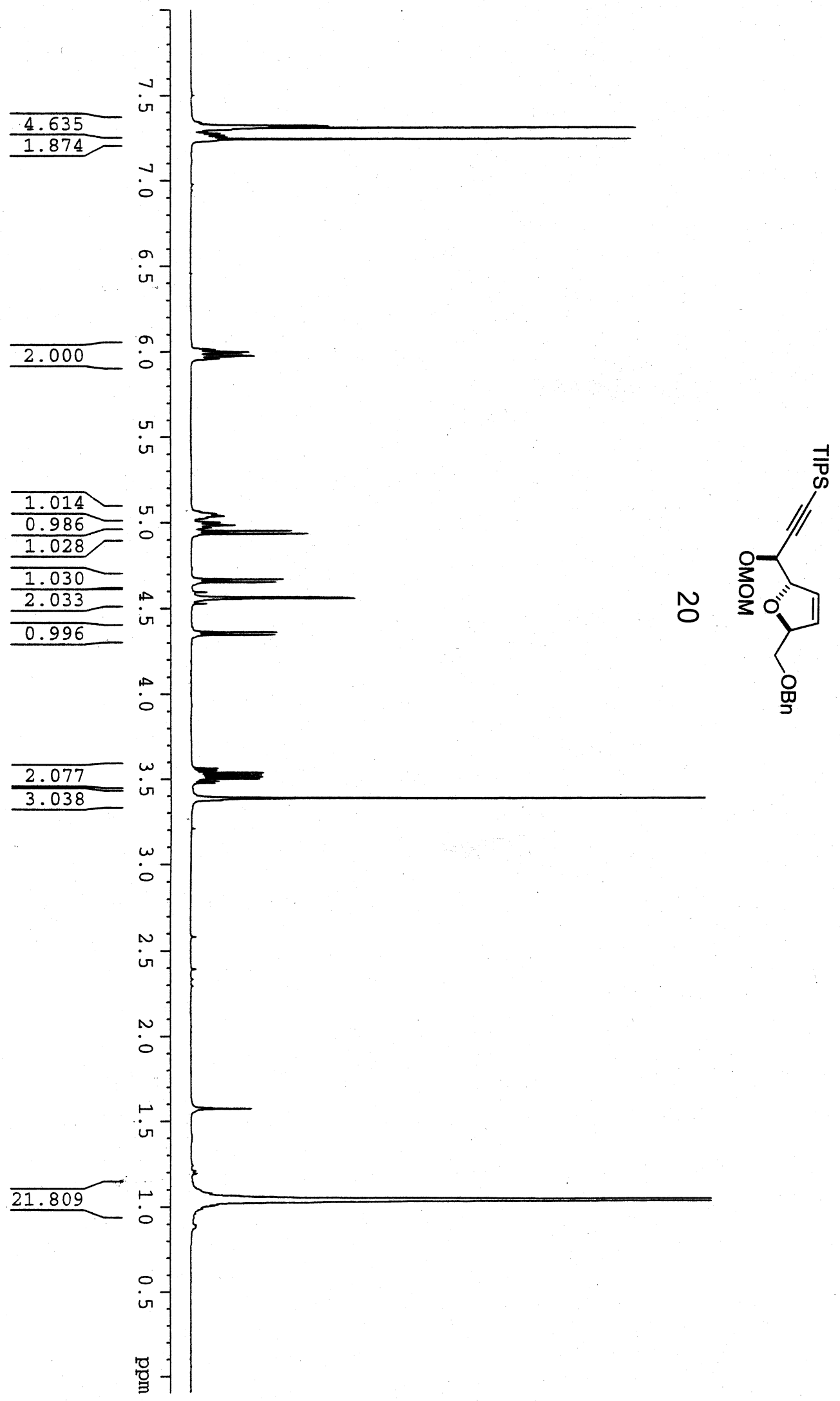




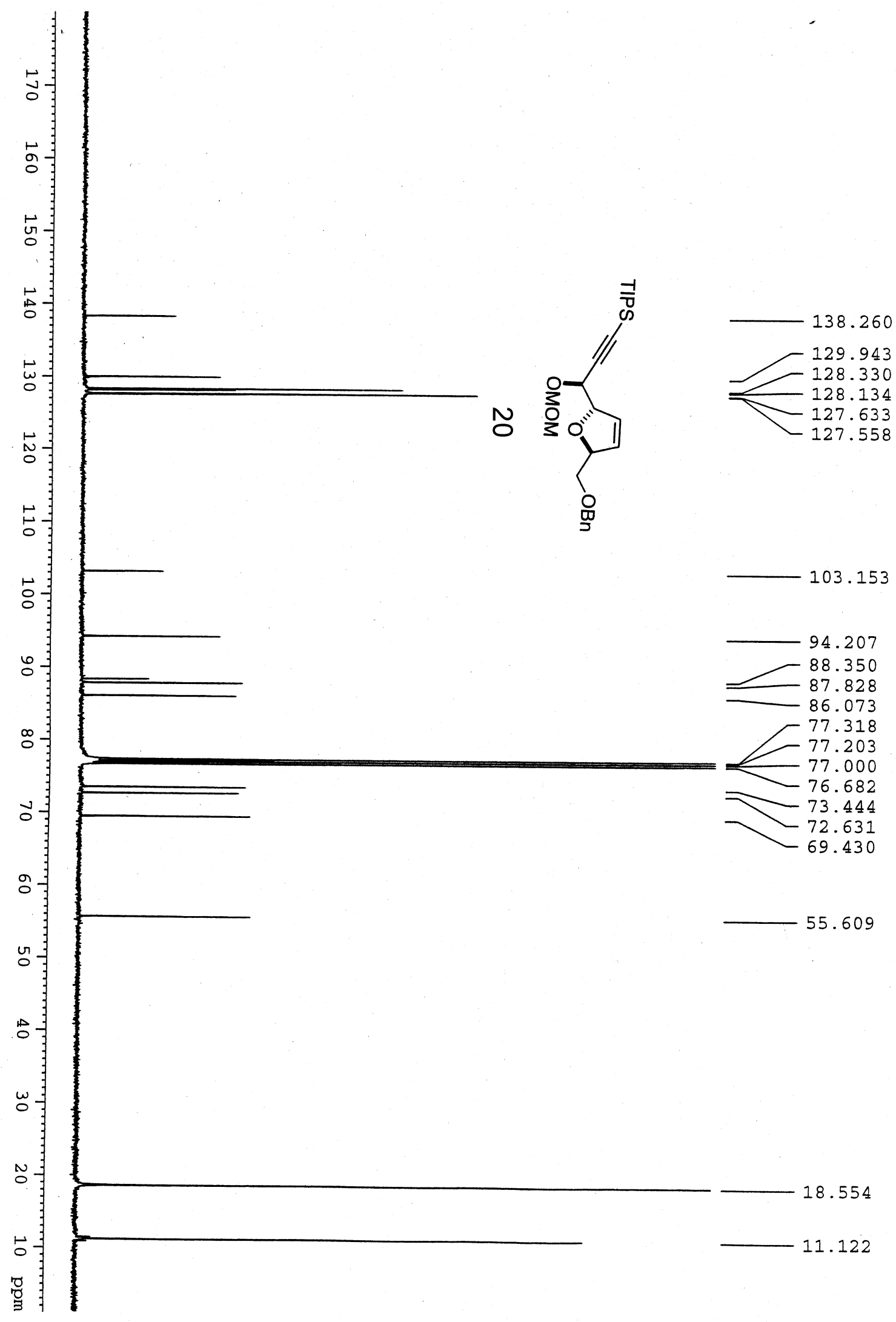




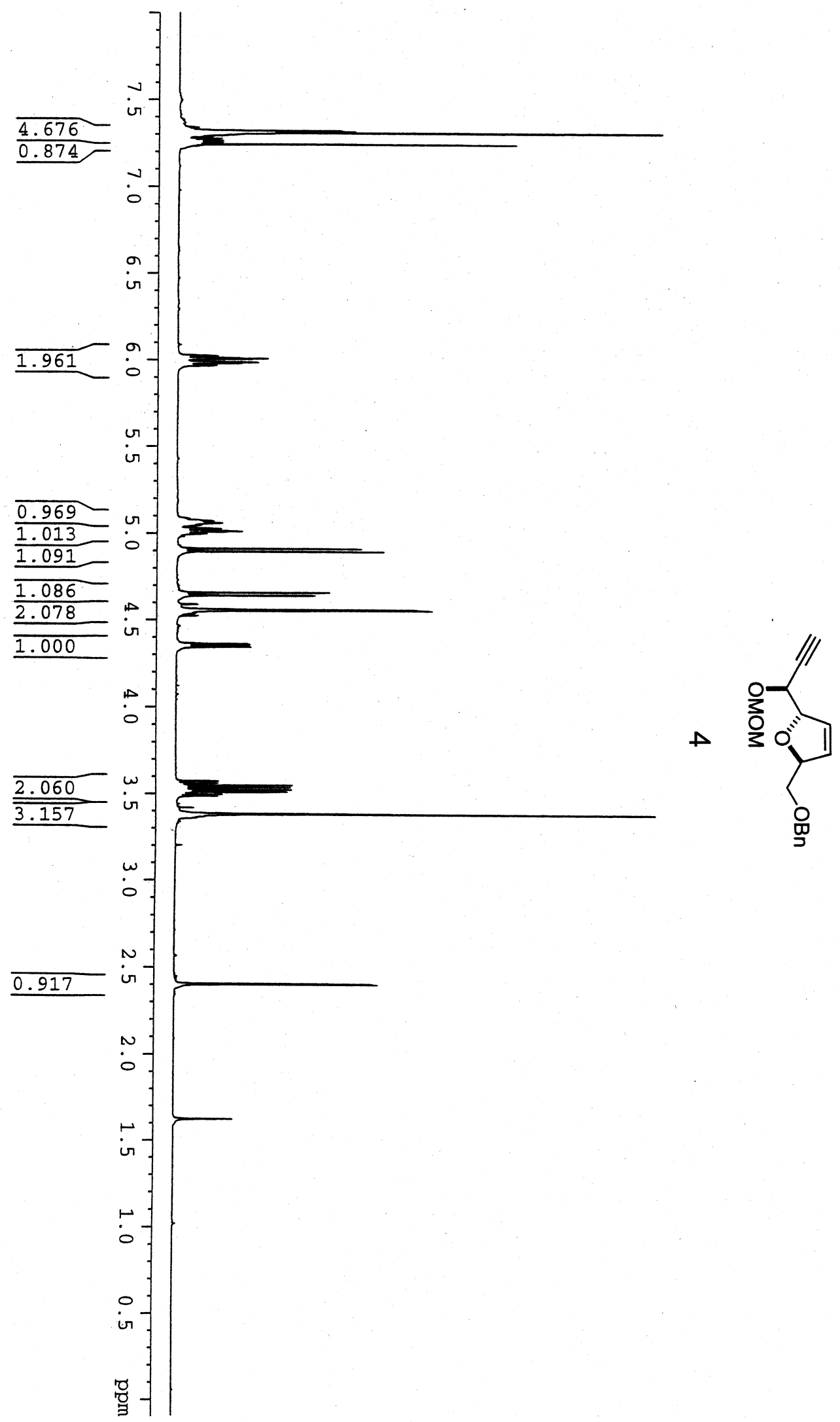




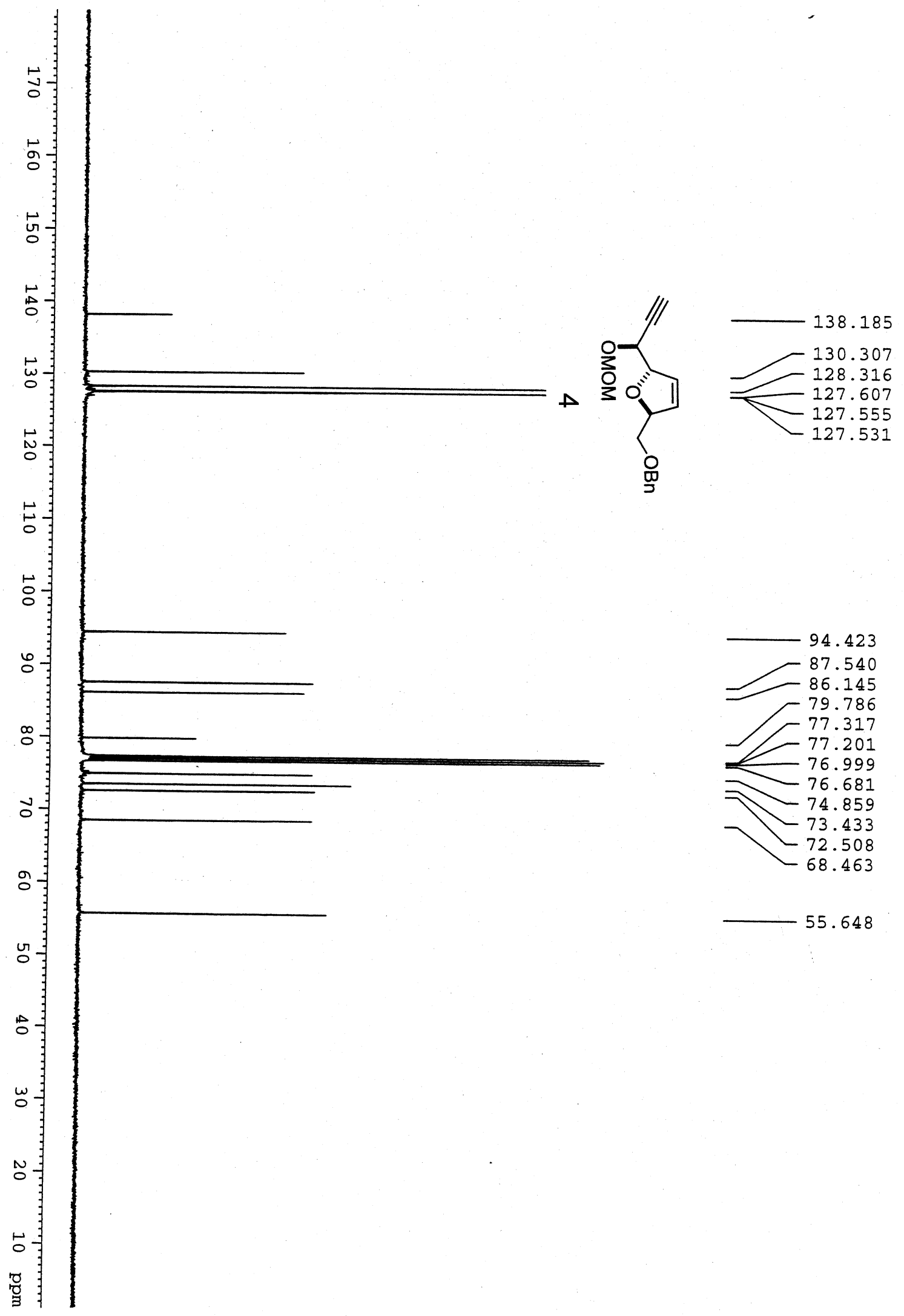




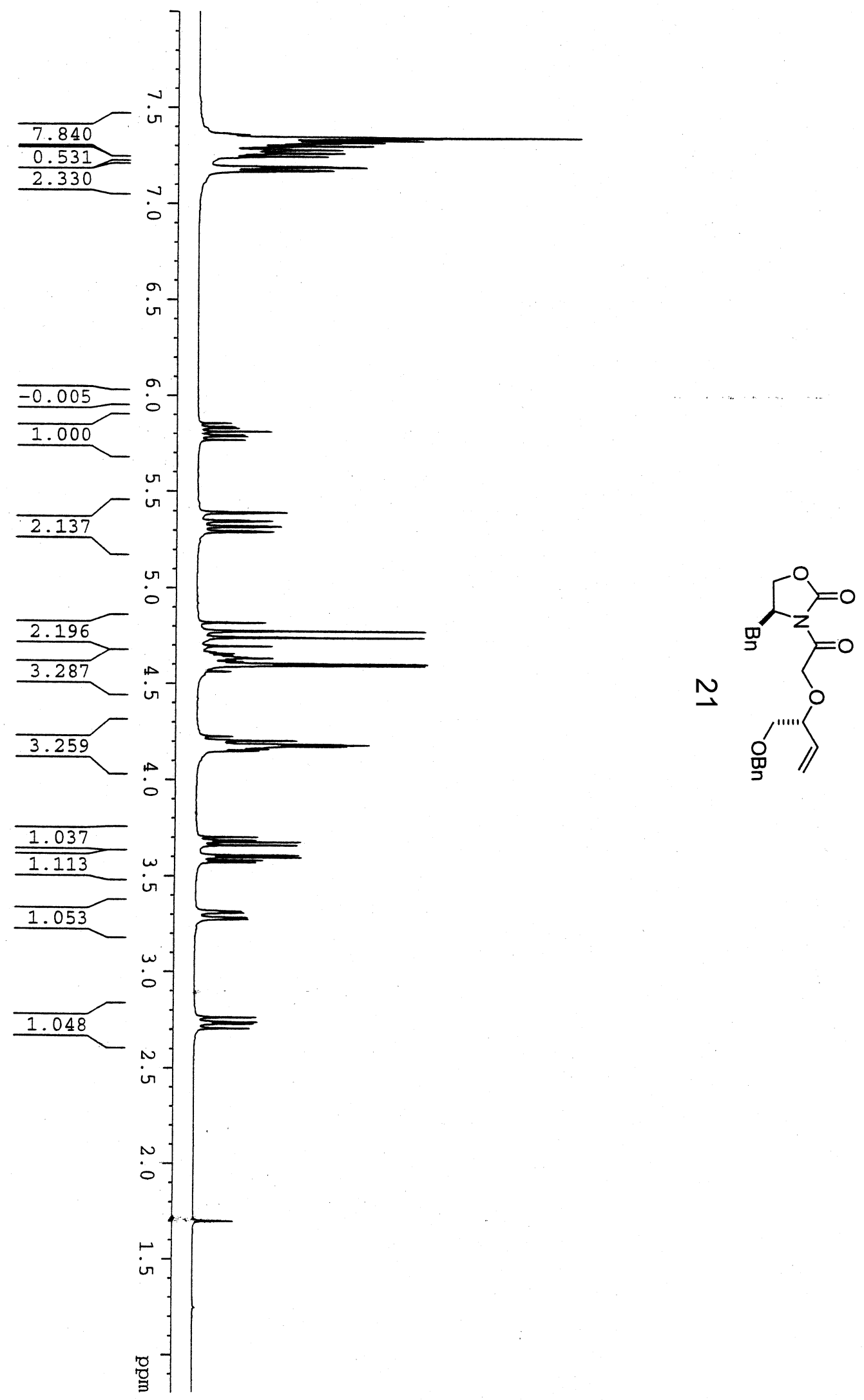




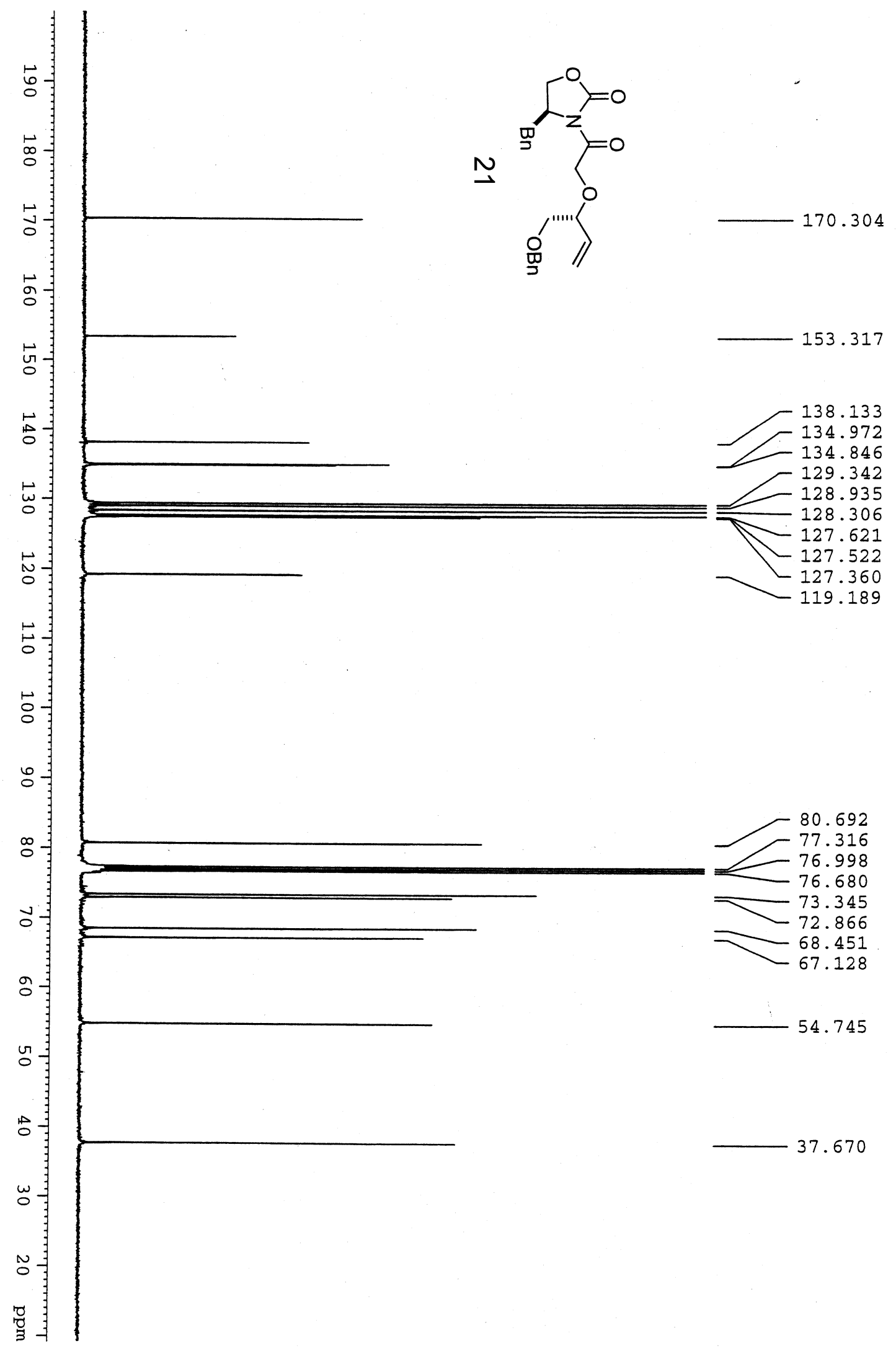




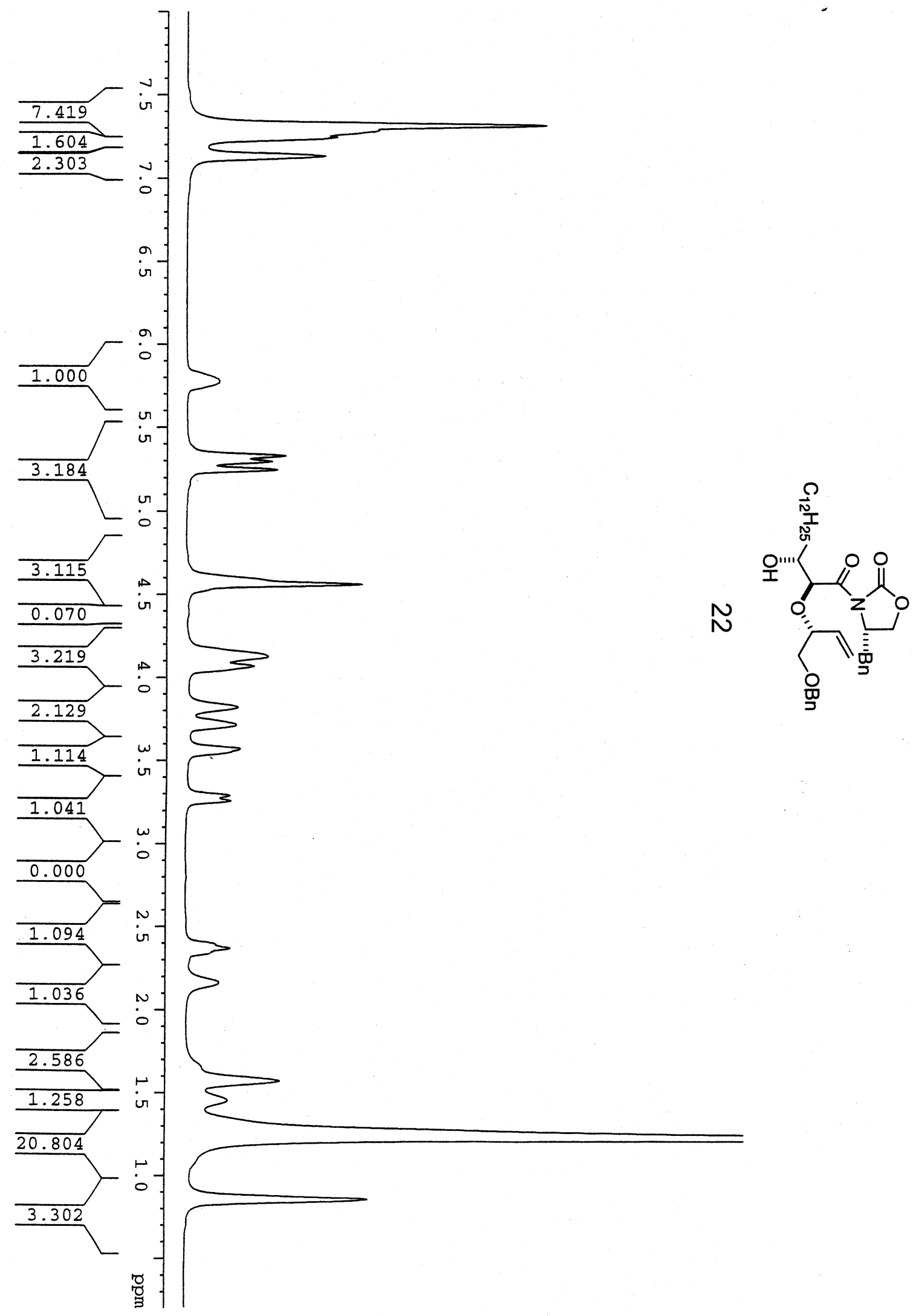




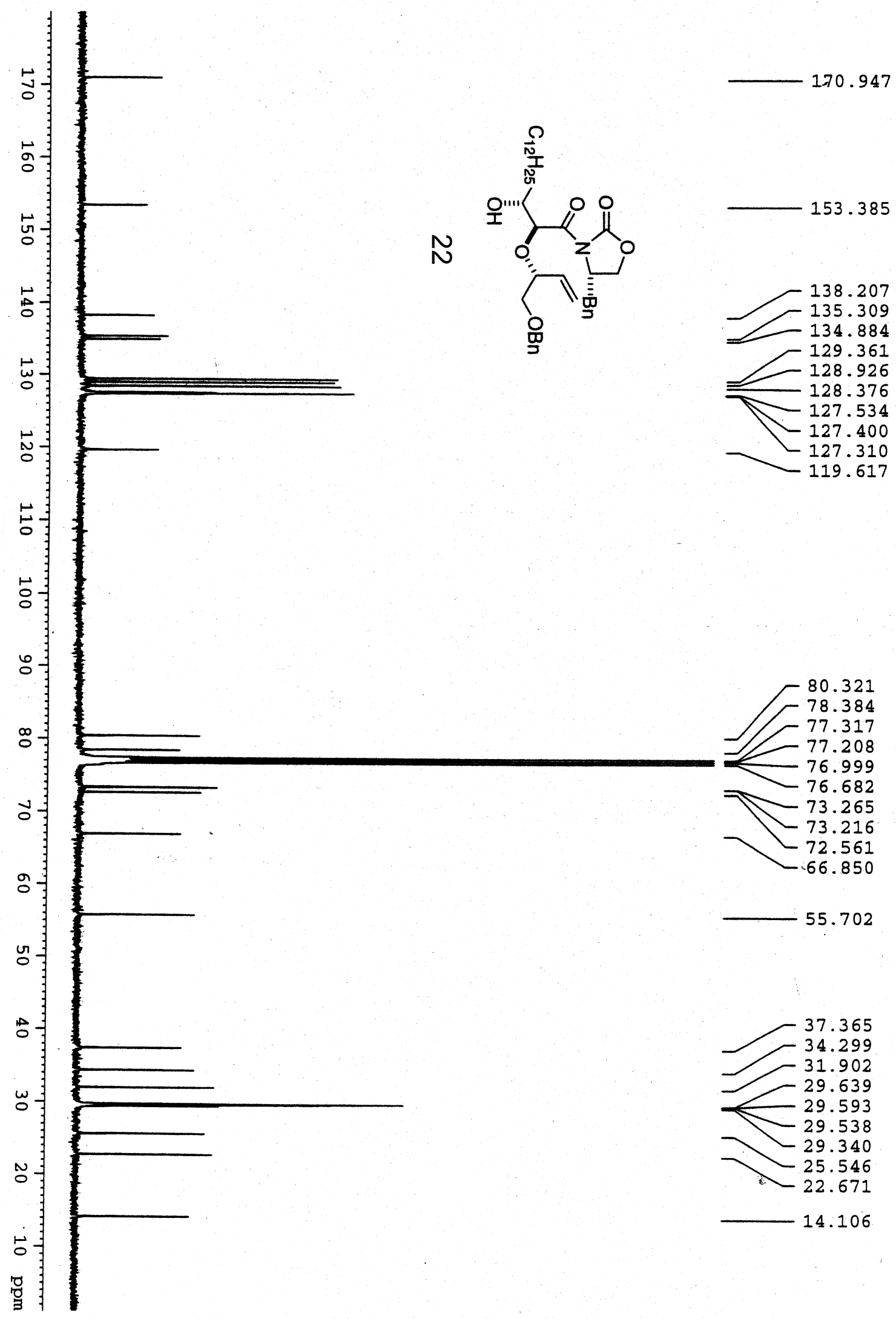



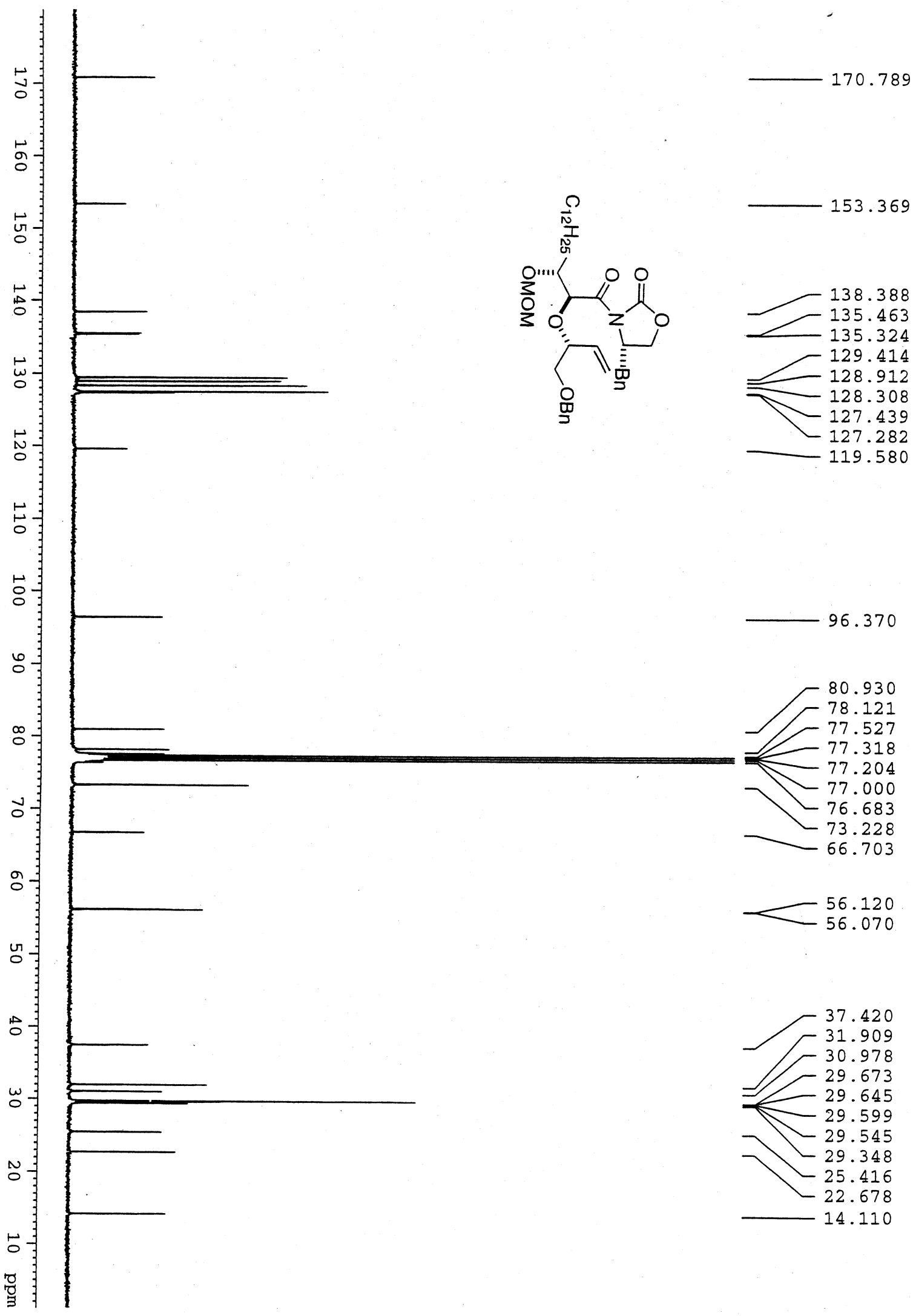


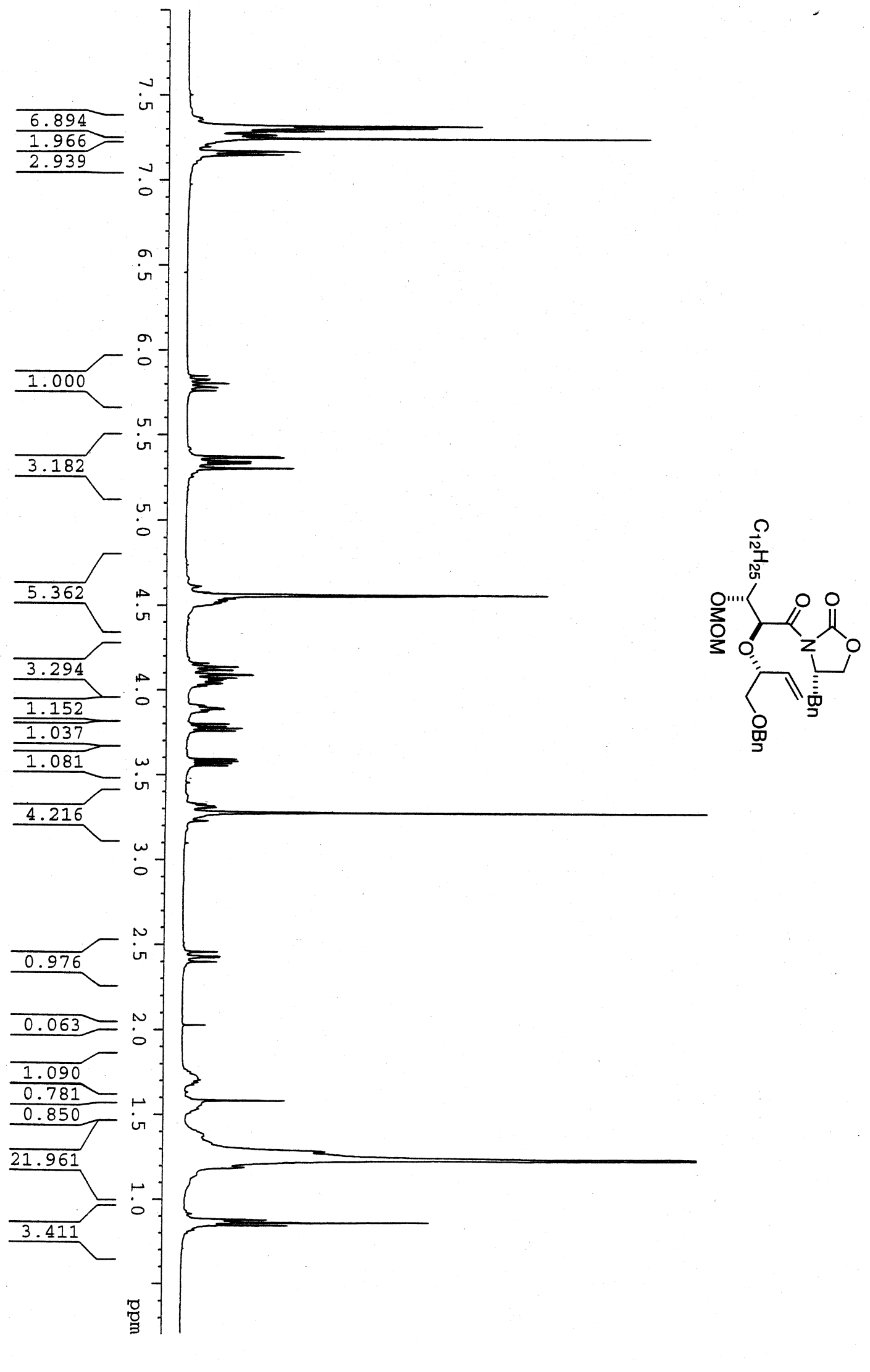




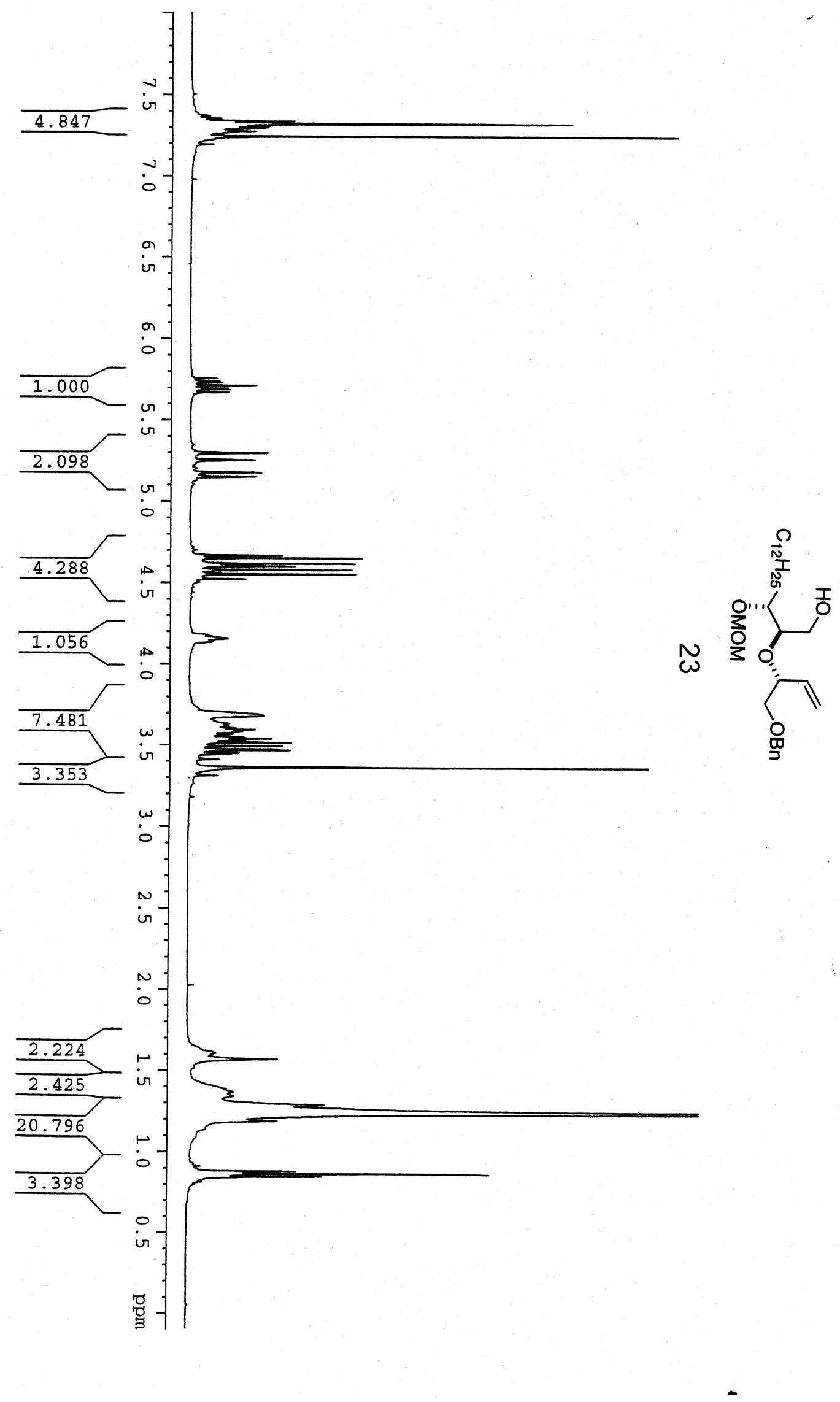



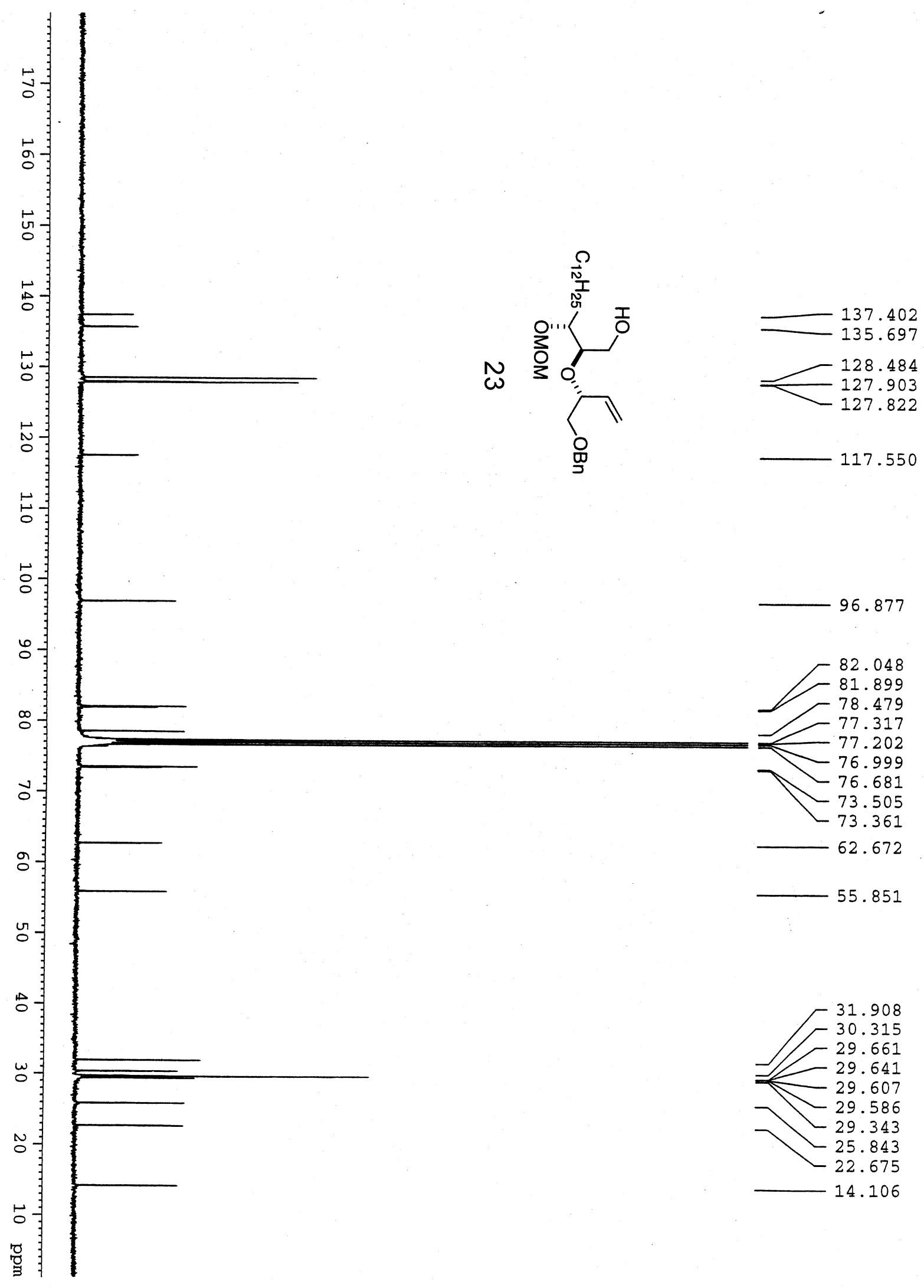

117.550

96.877
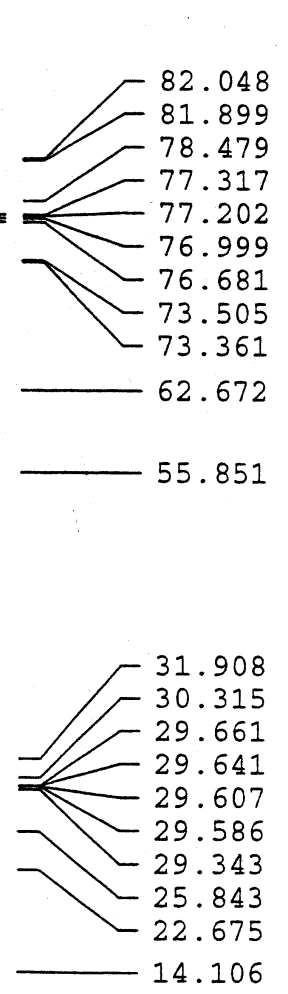


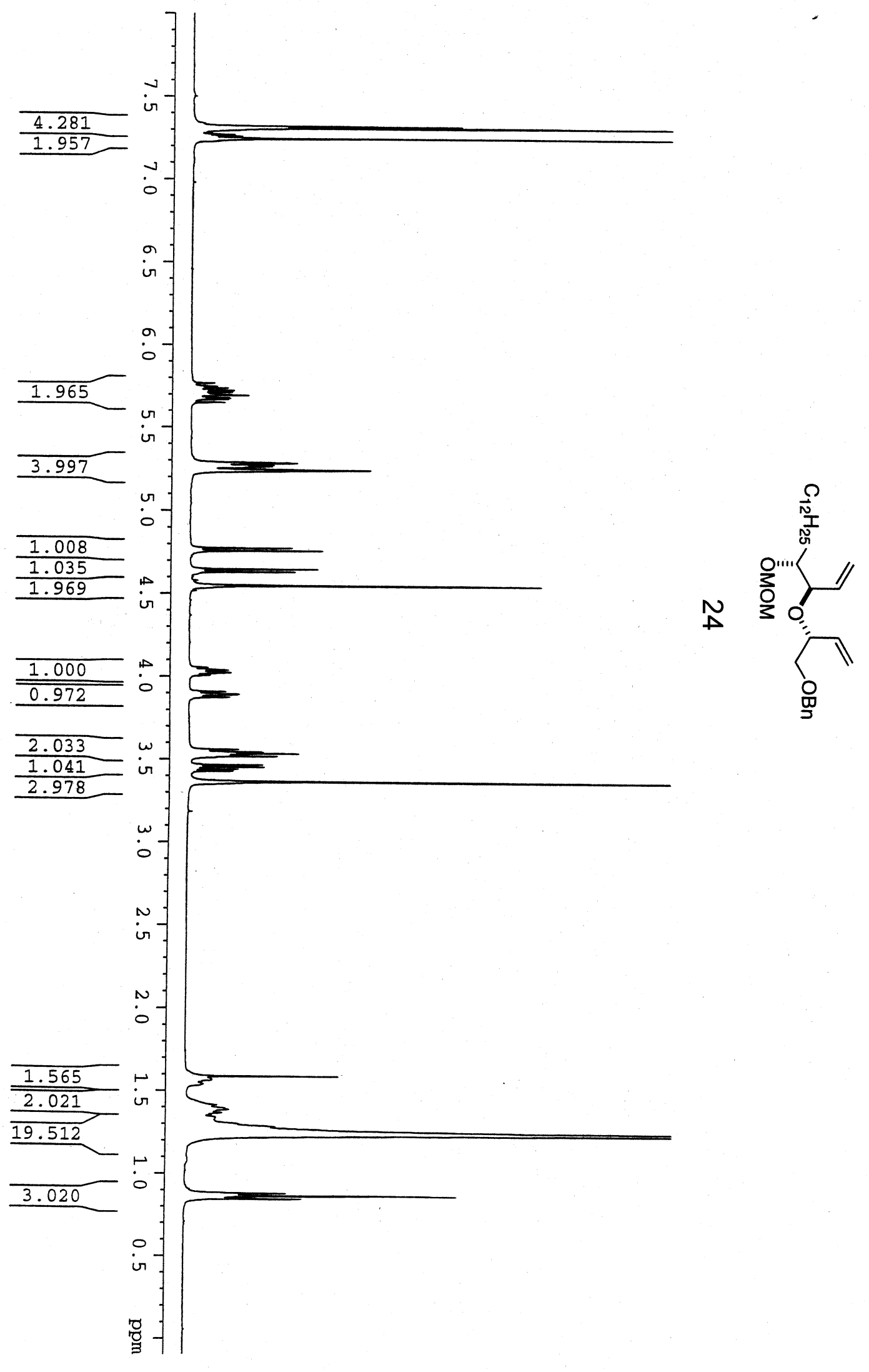




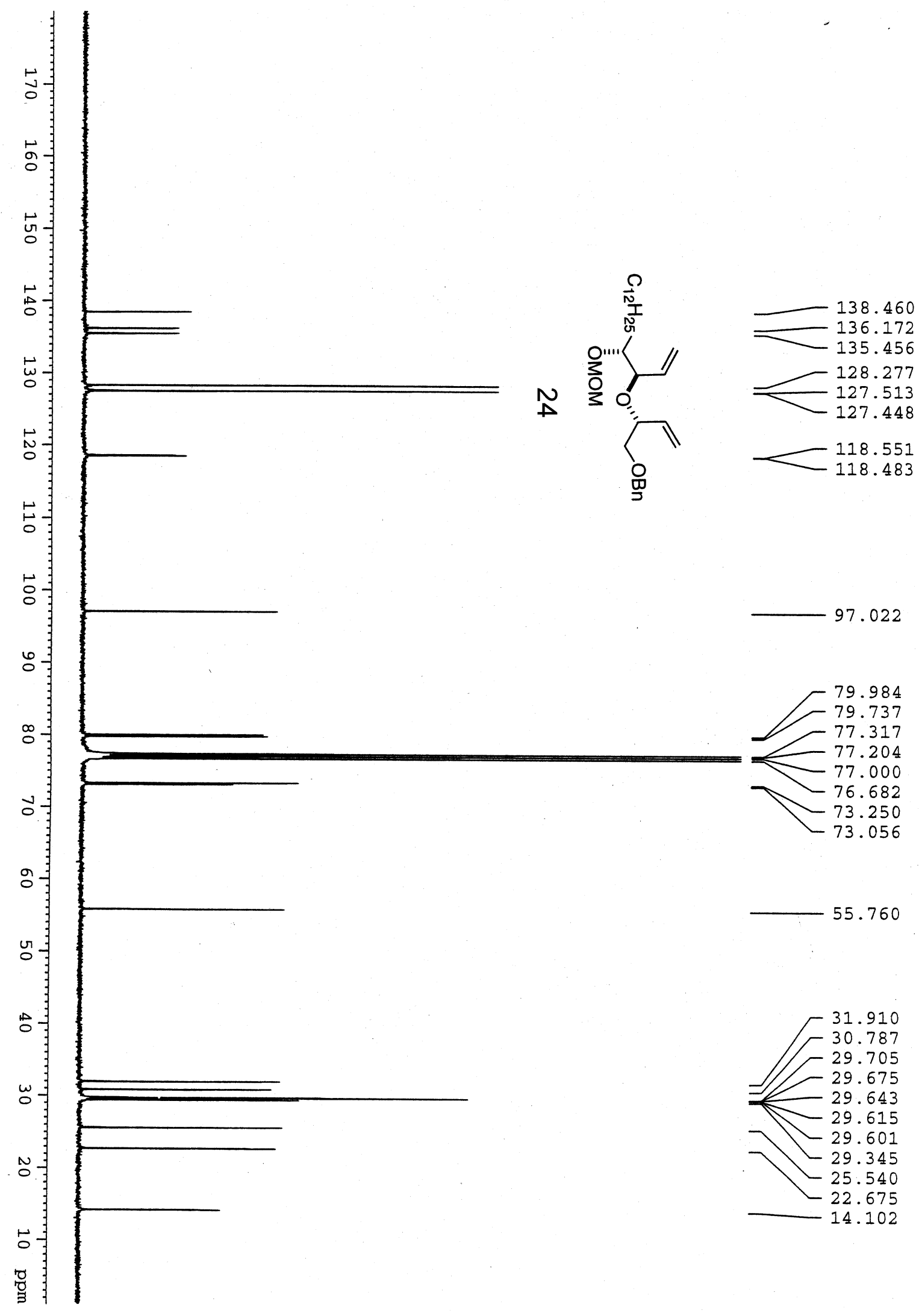




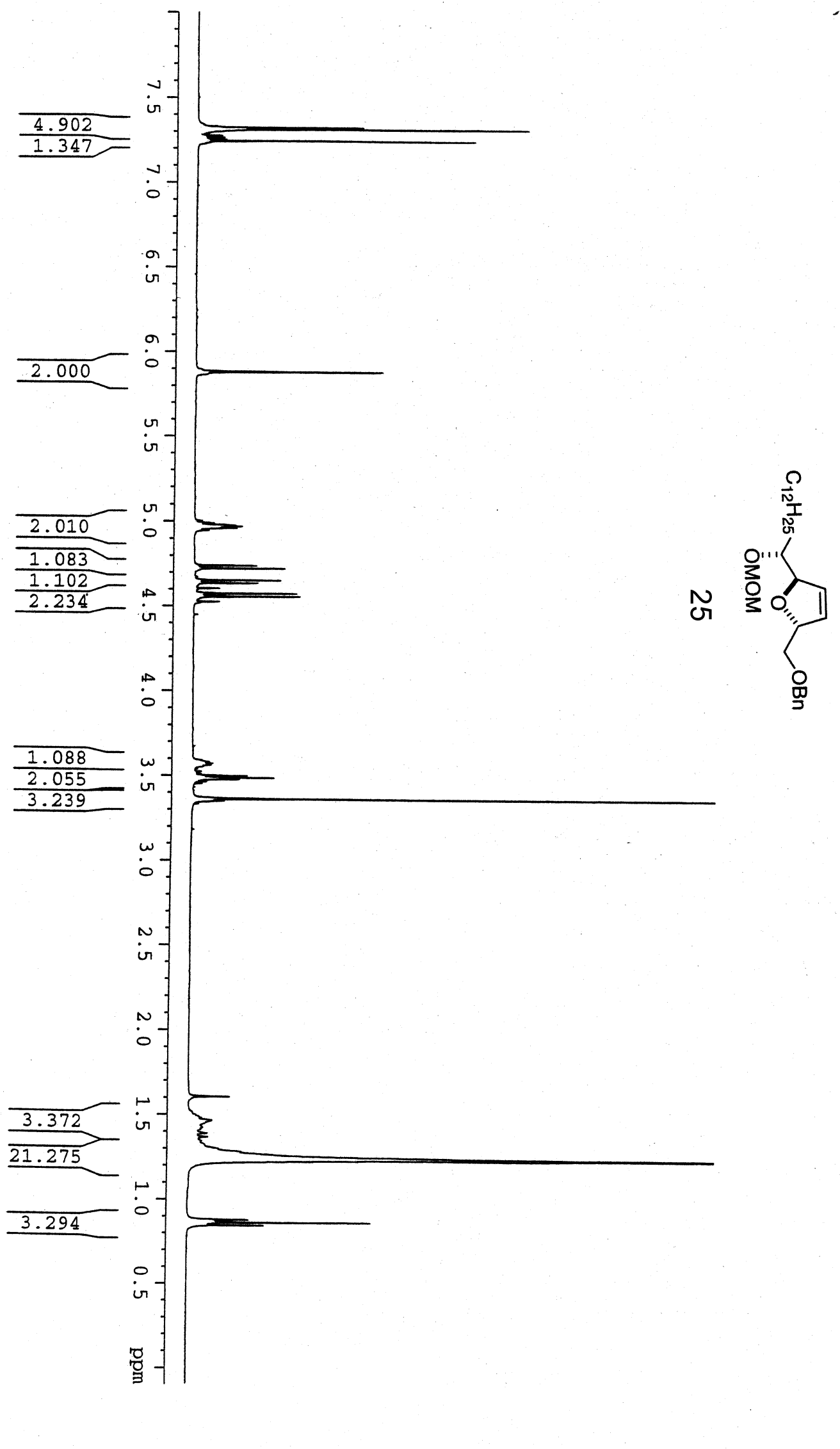



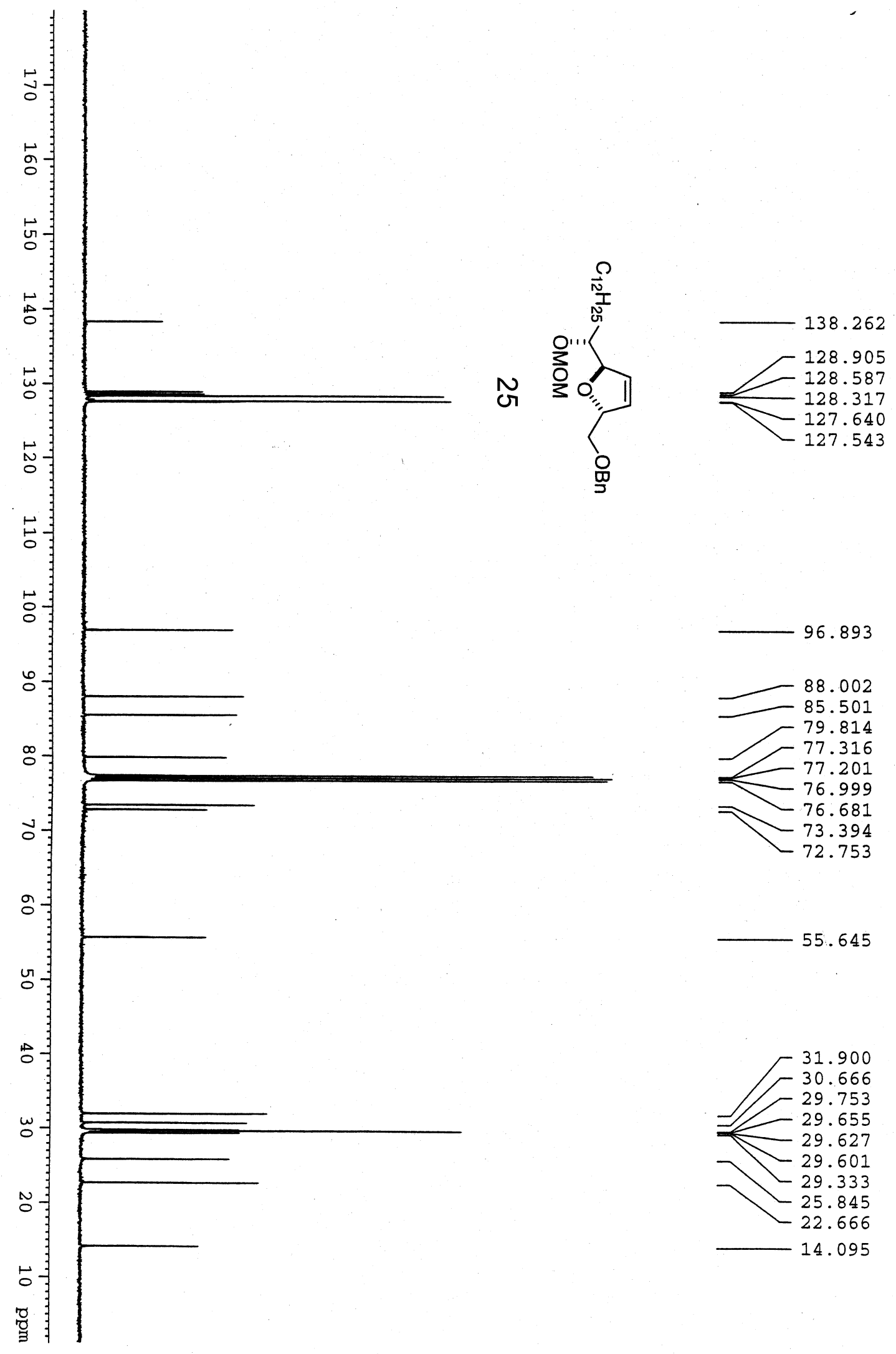


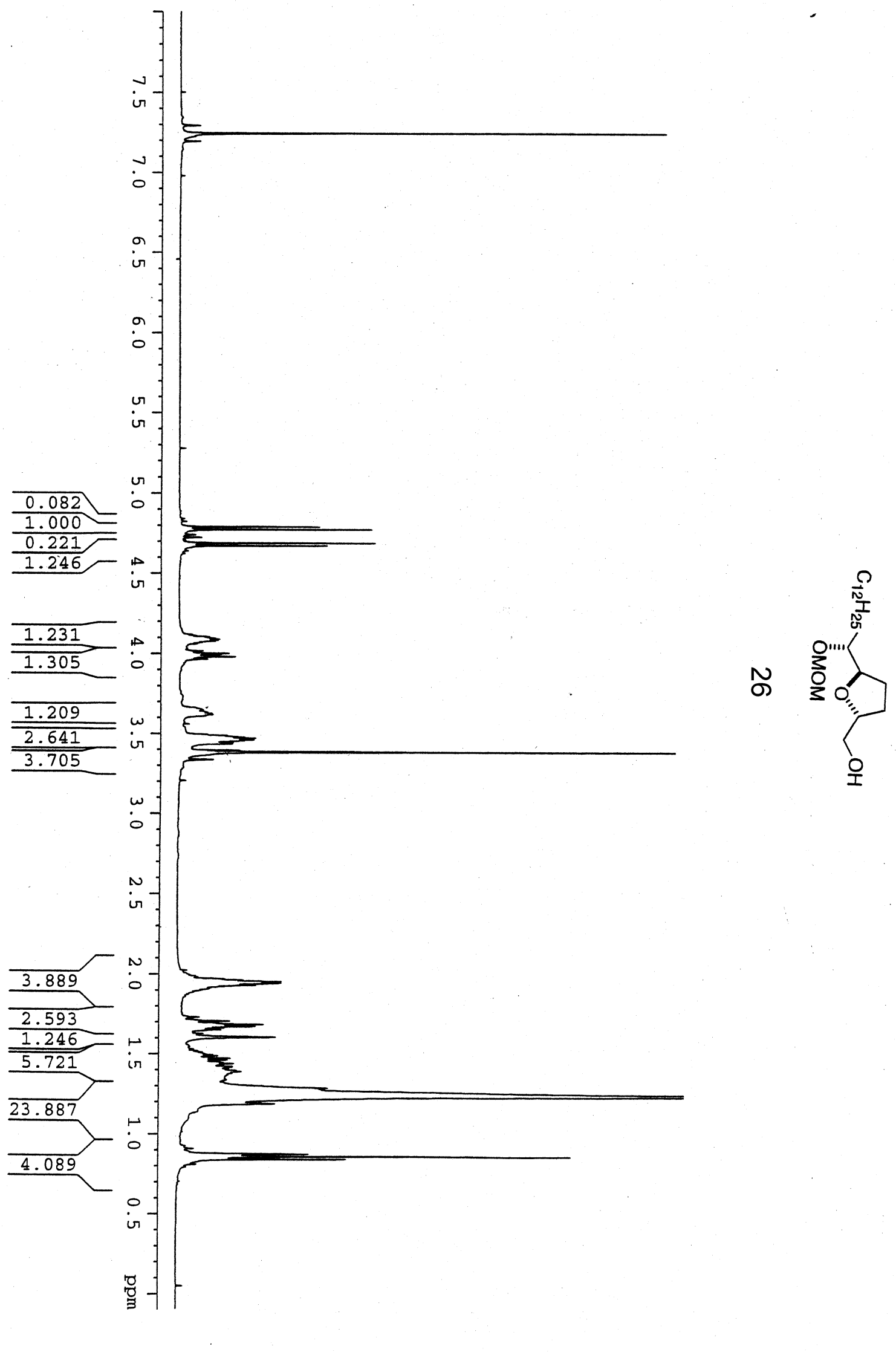




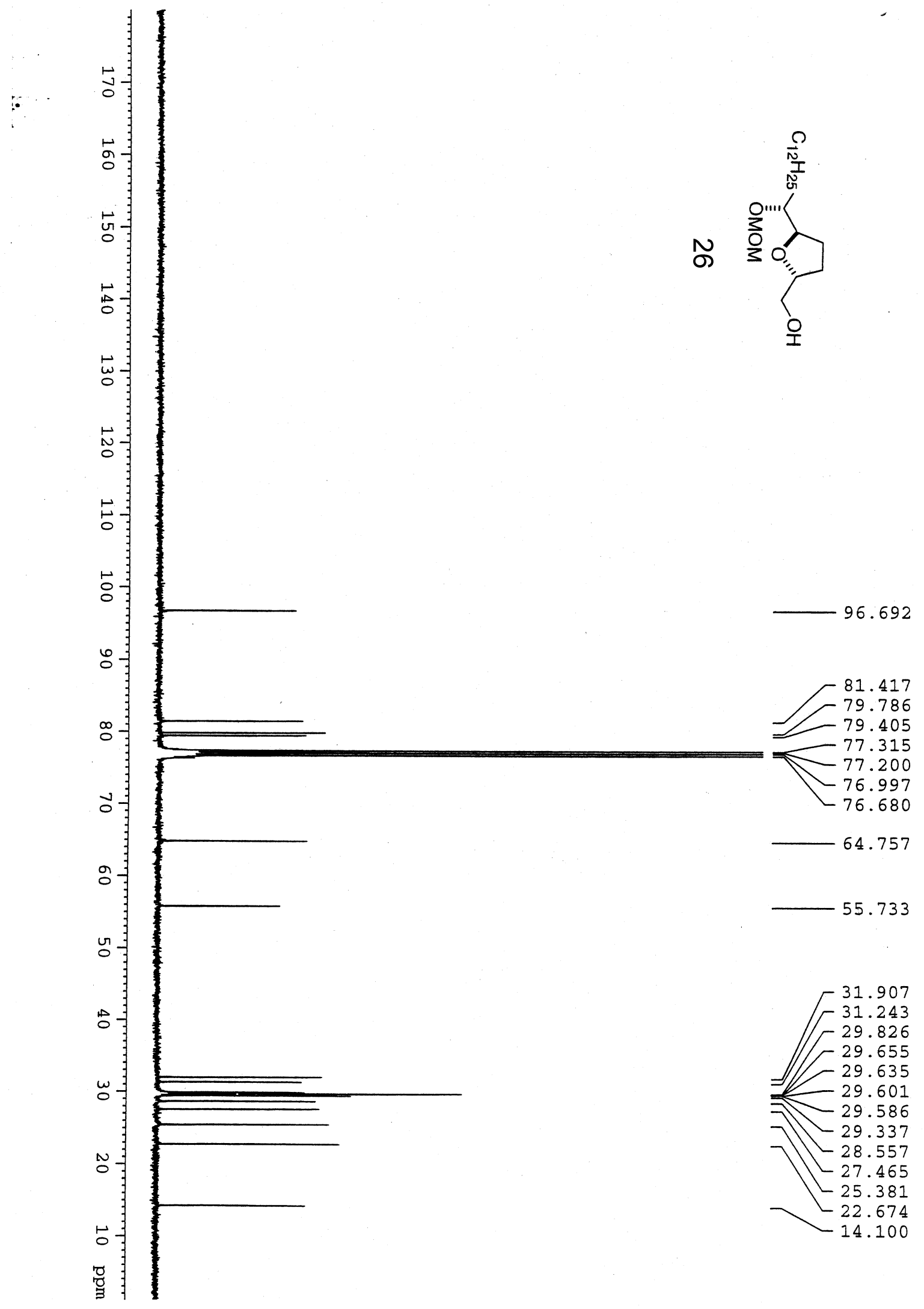




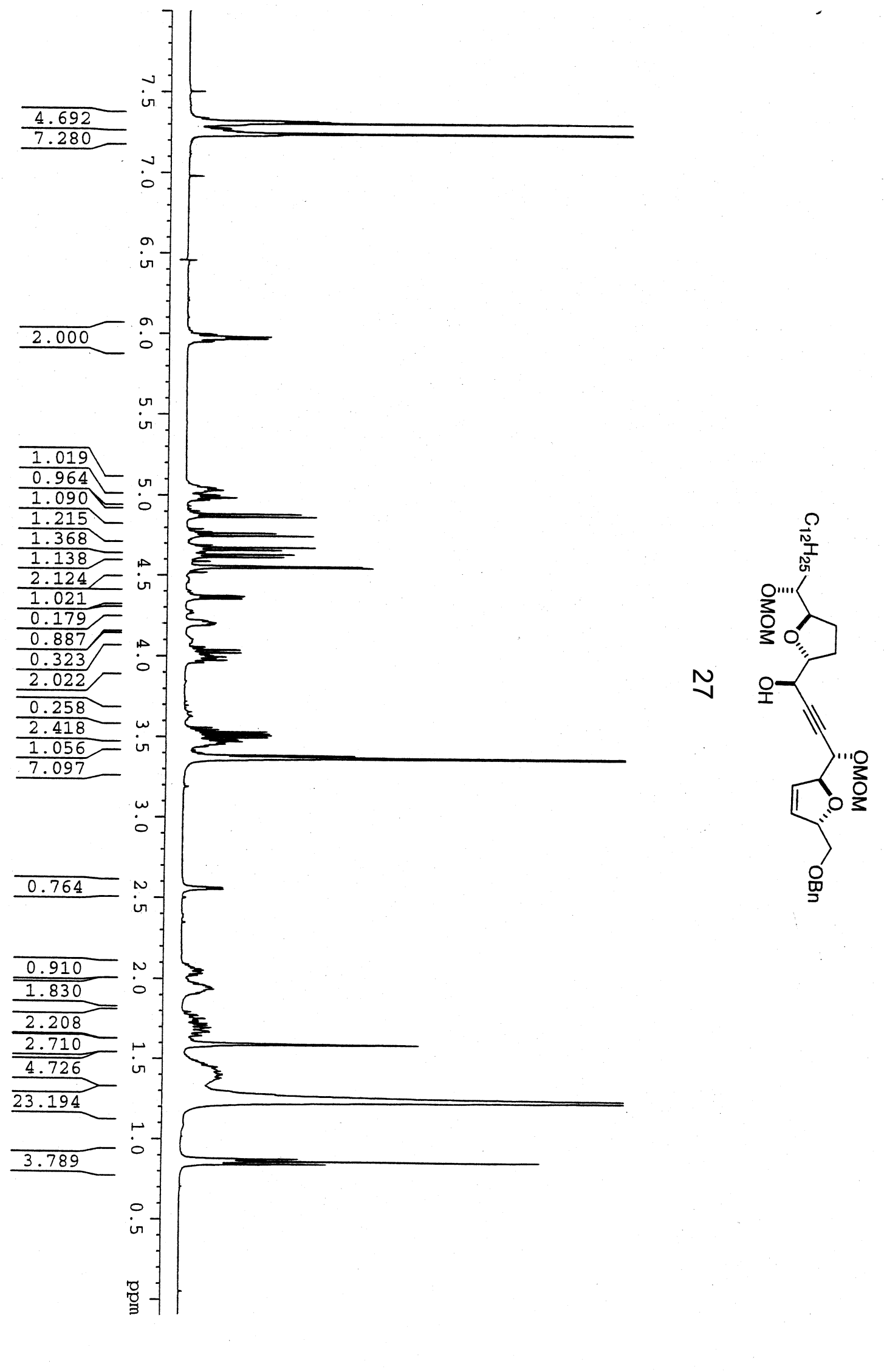




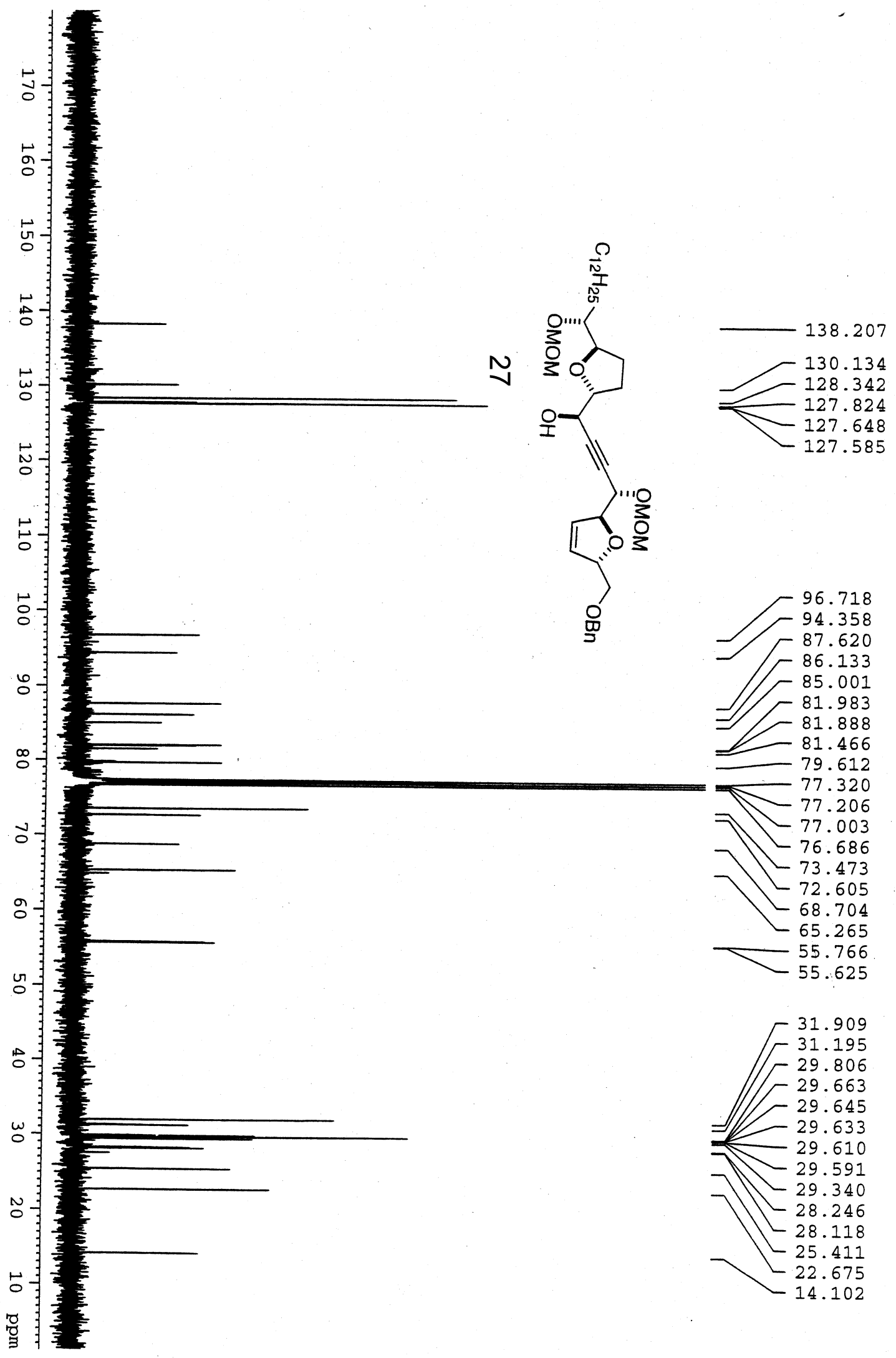




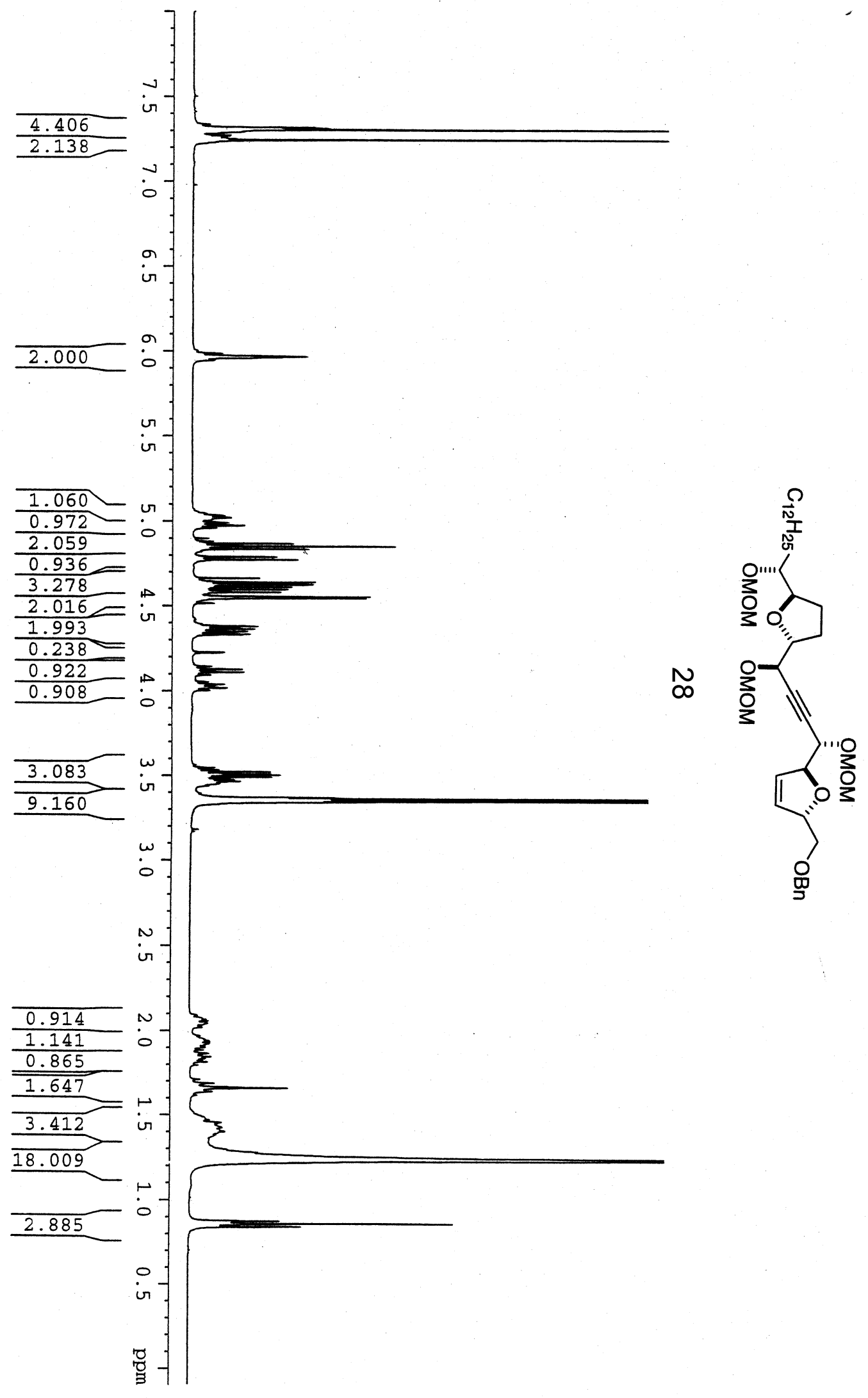




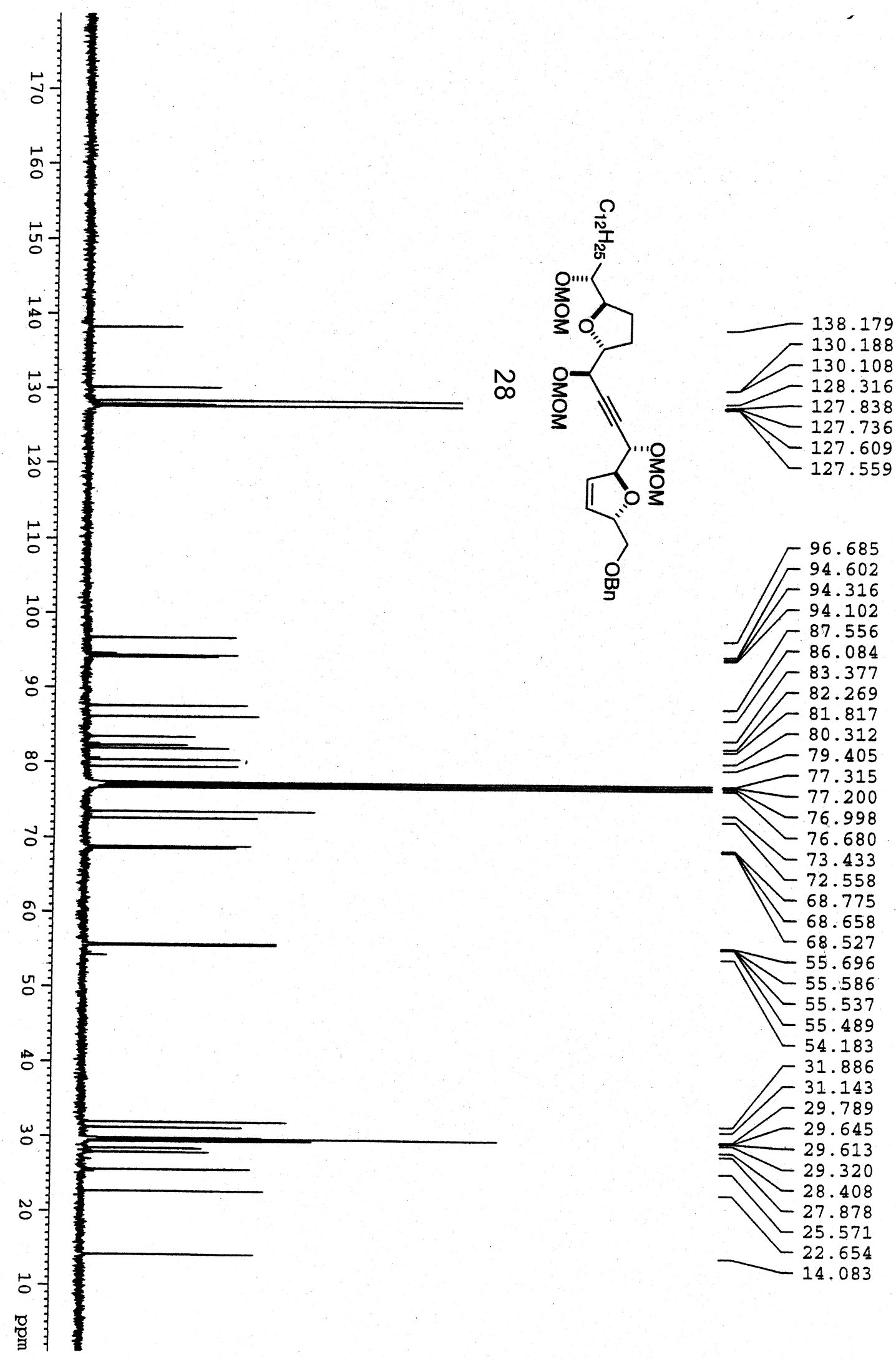




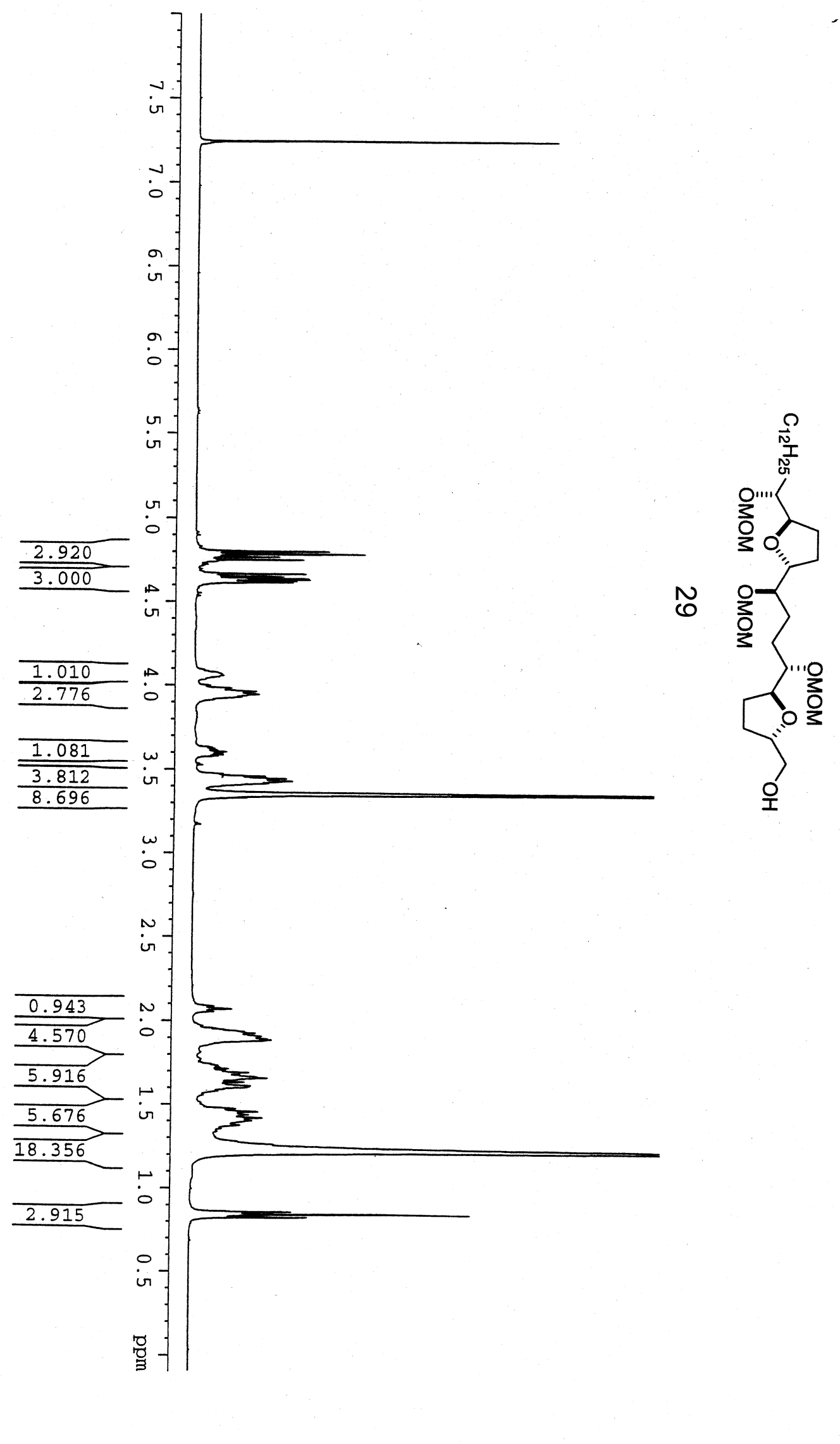



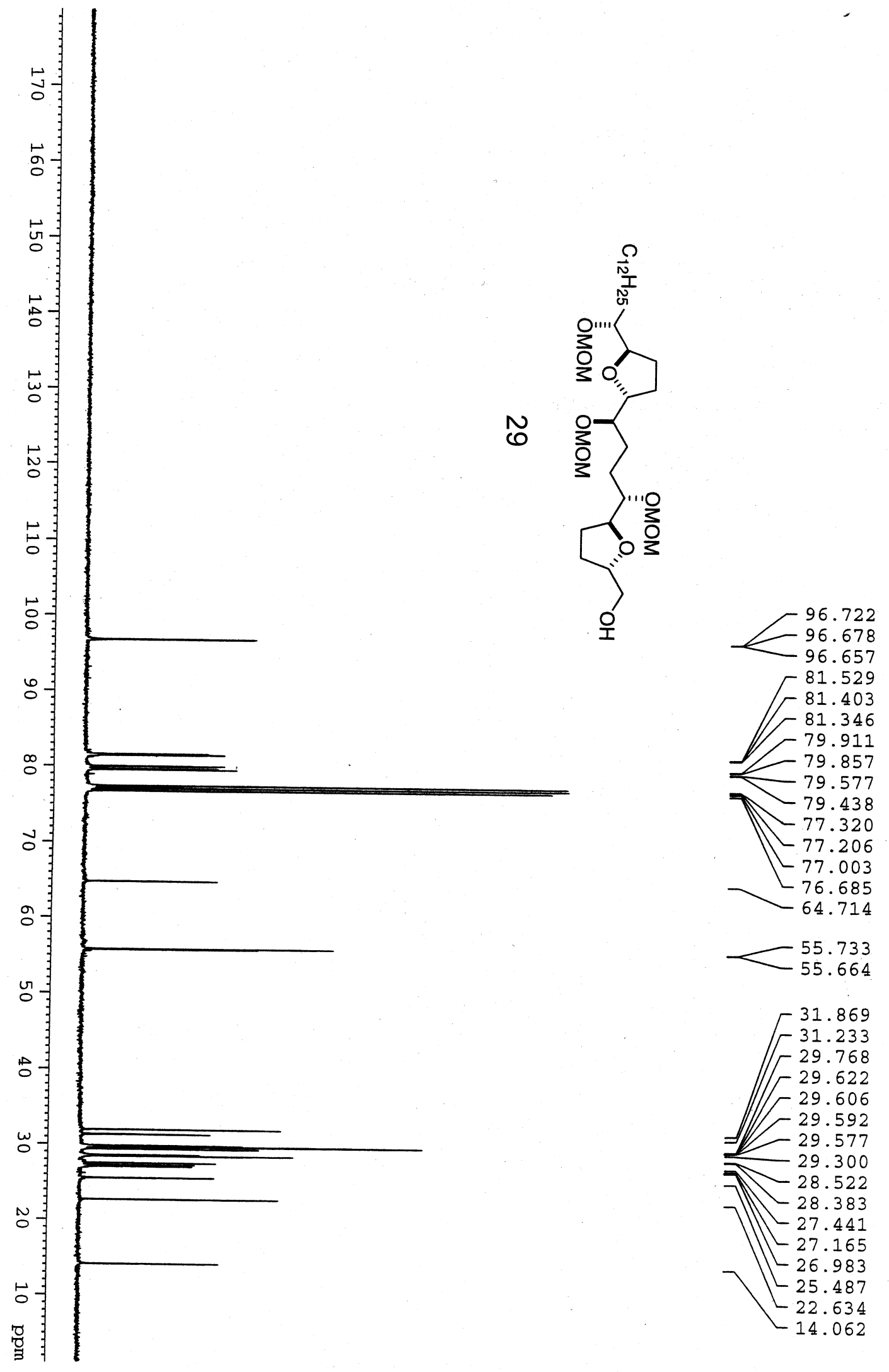


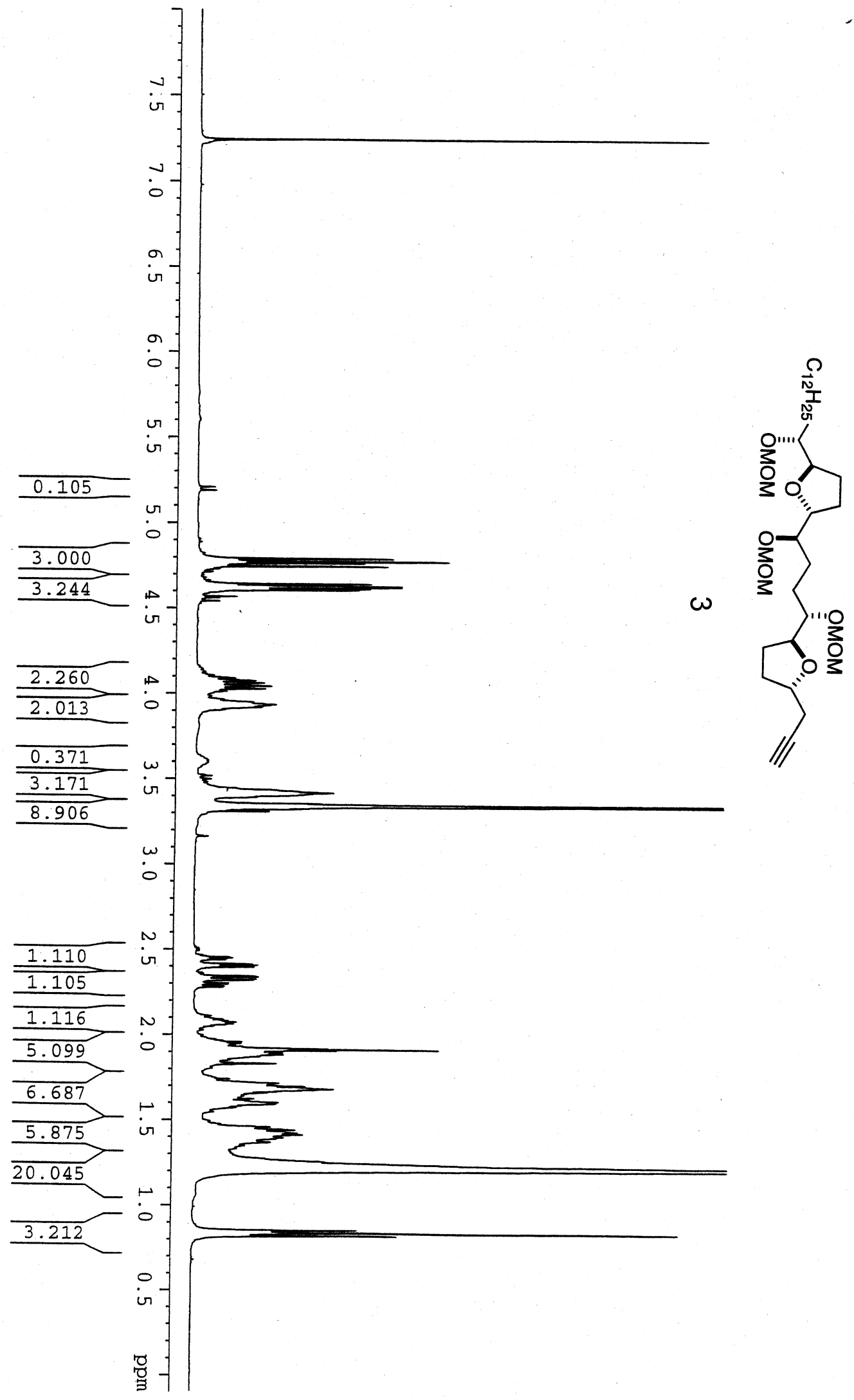



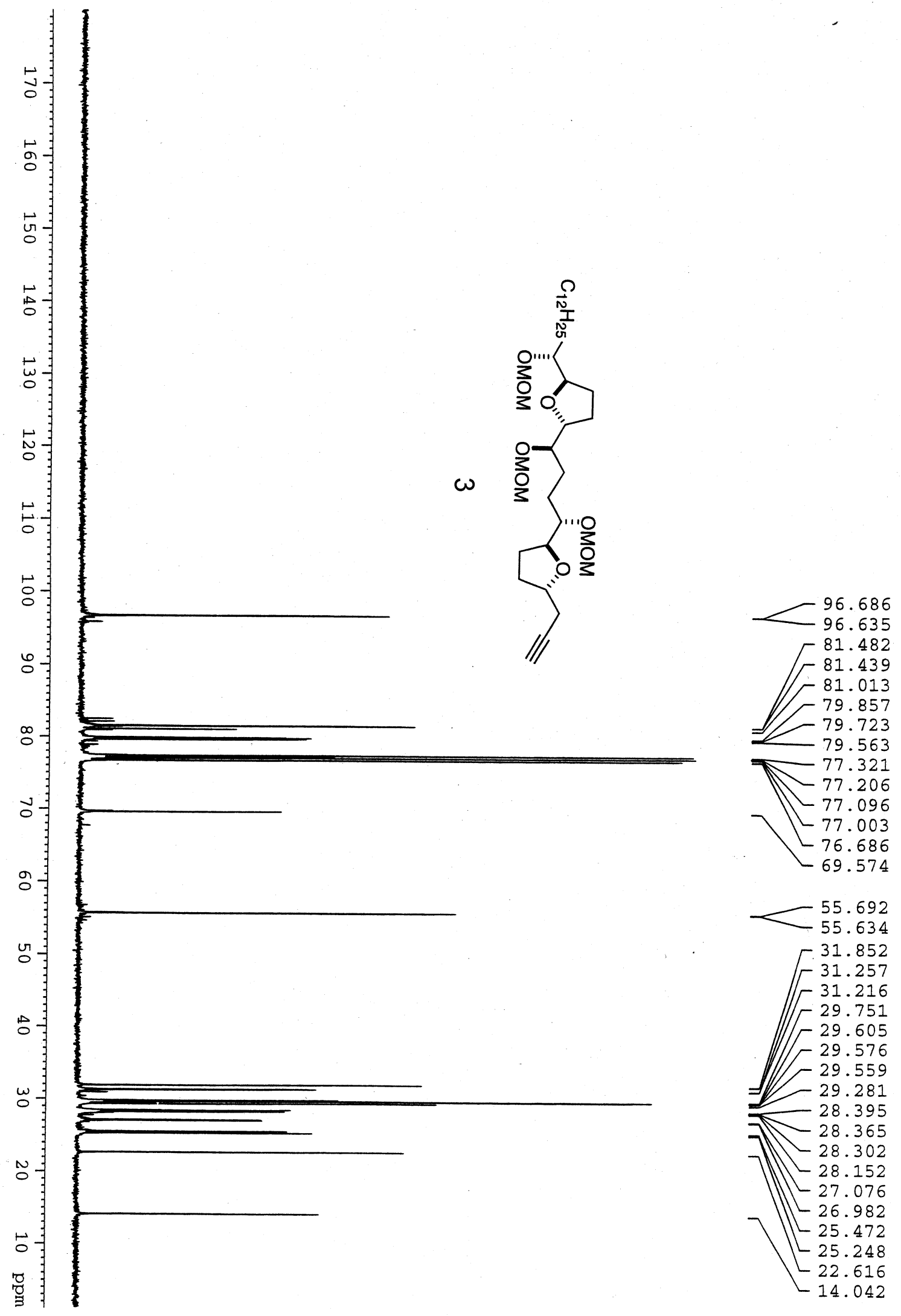


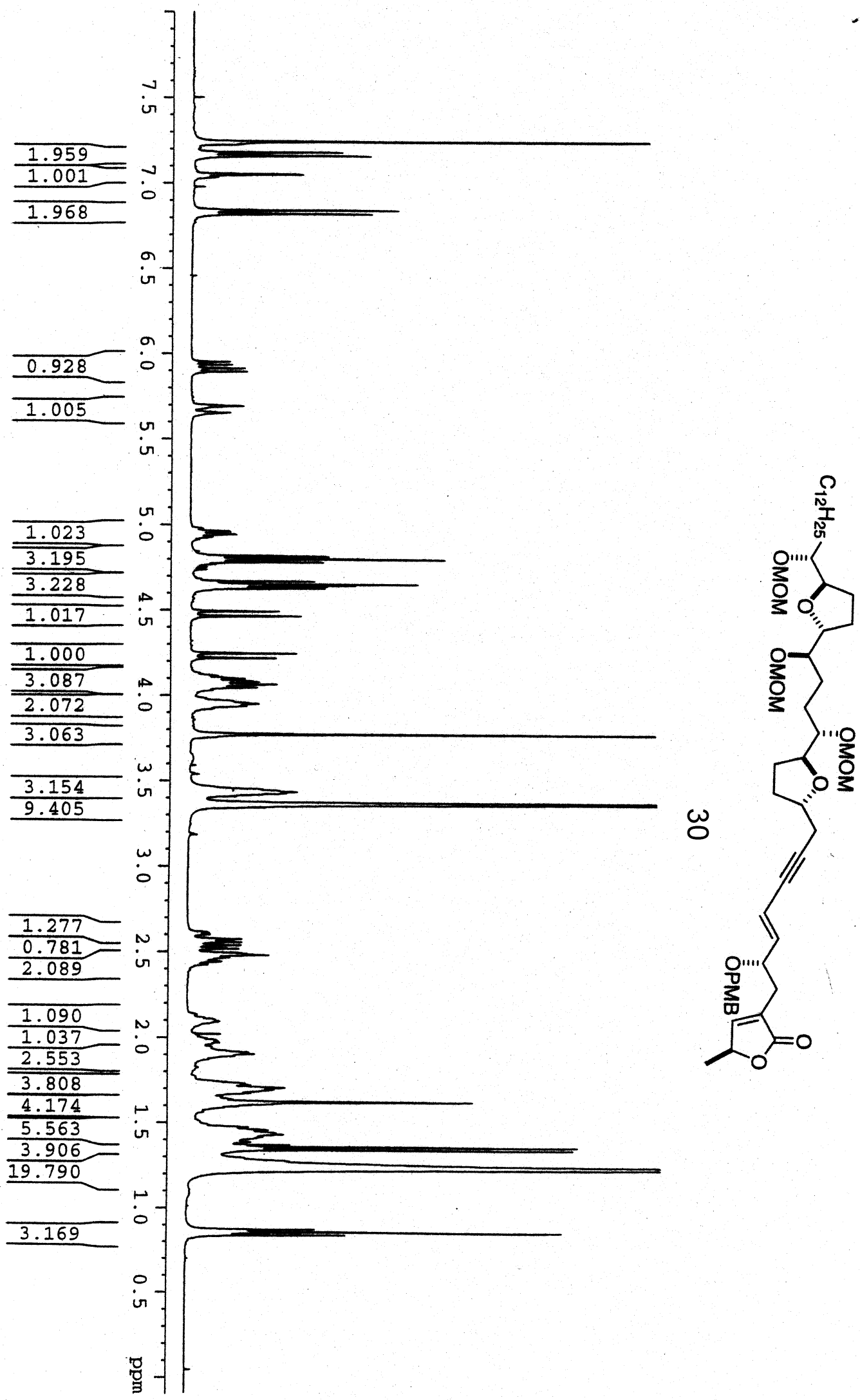




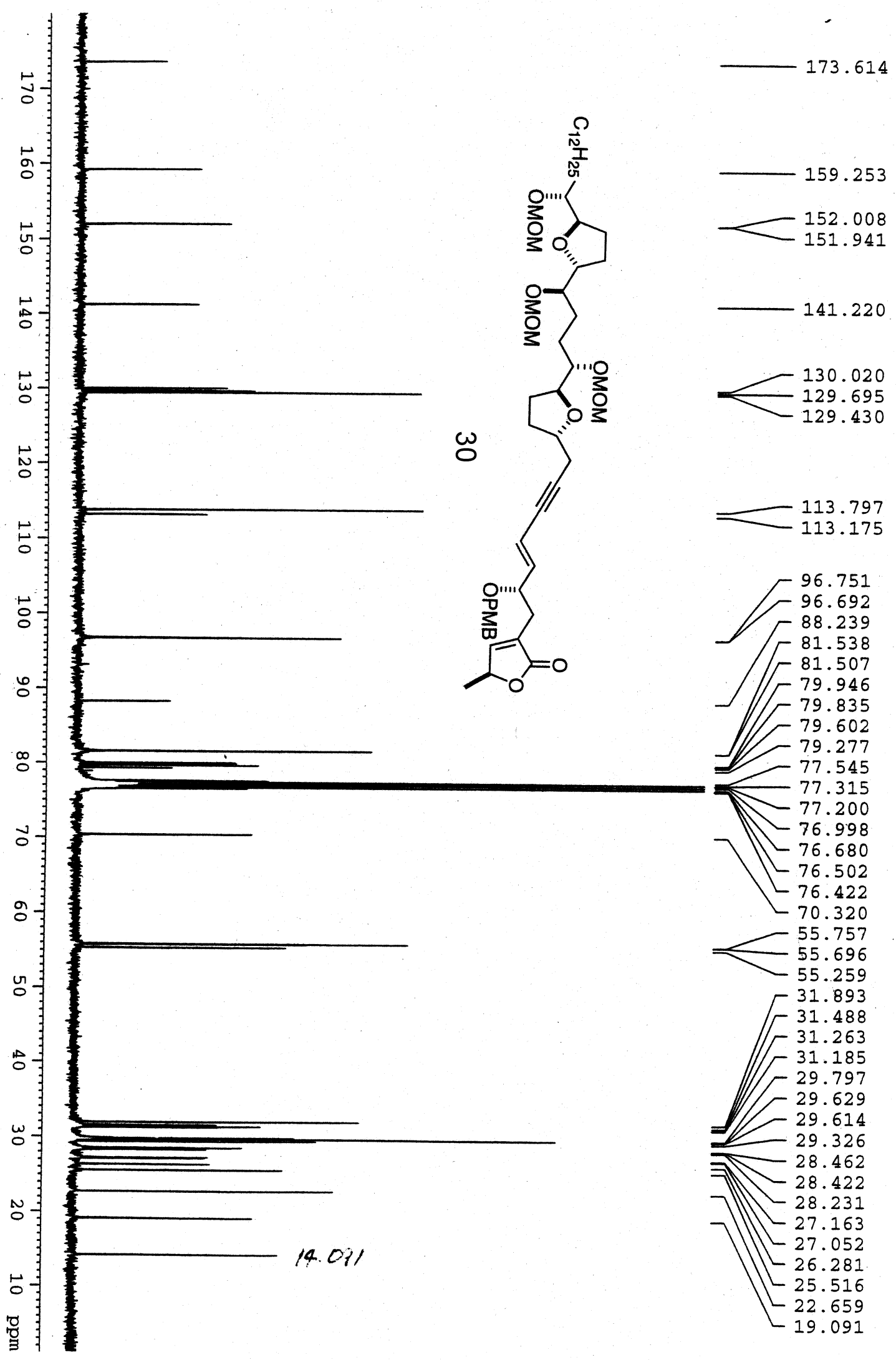




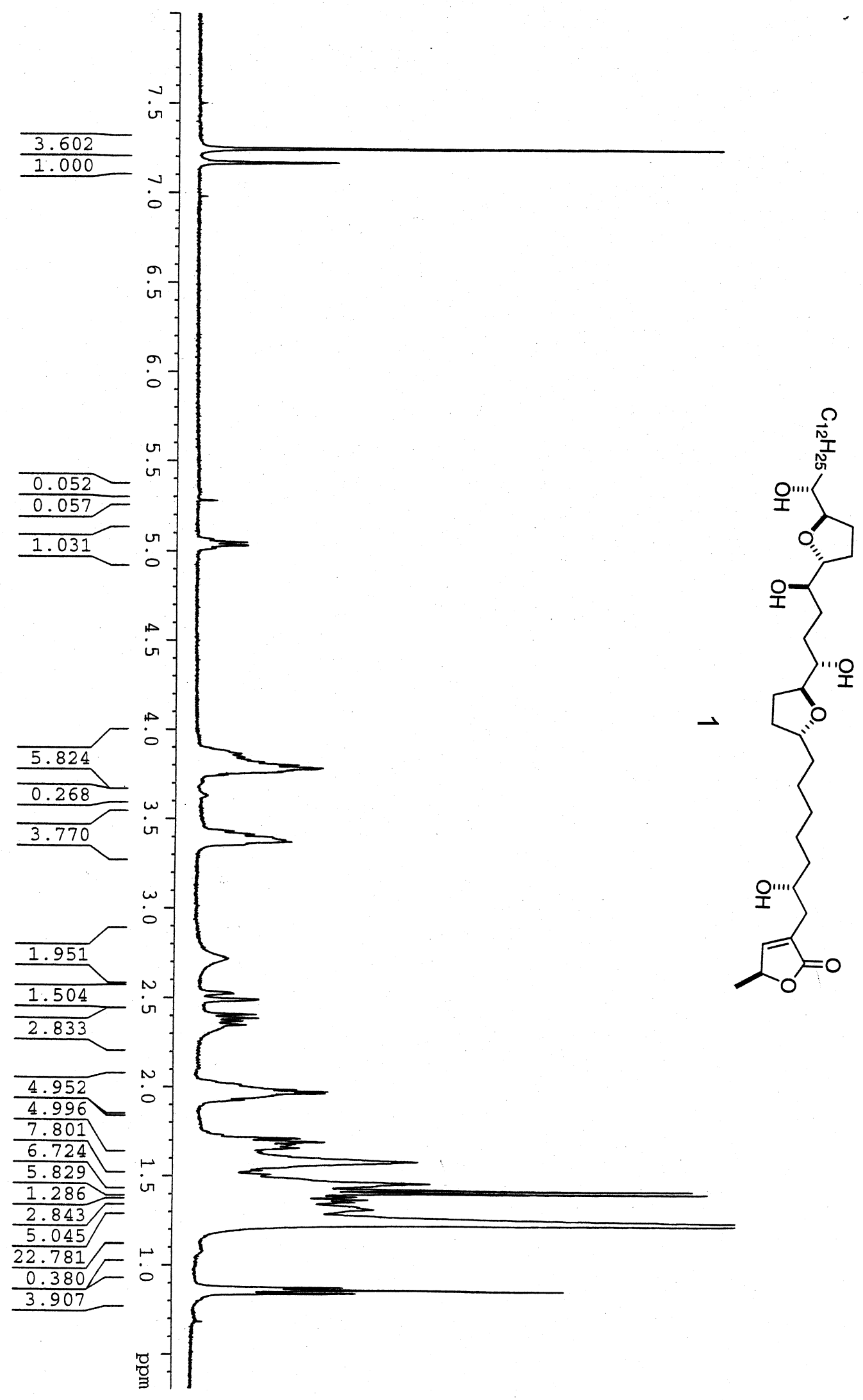




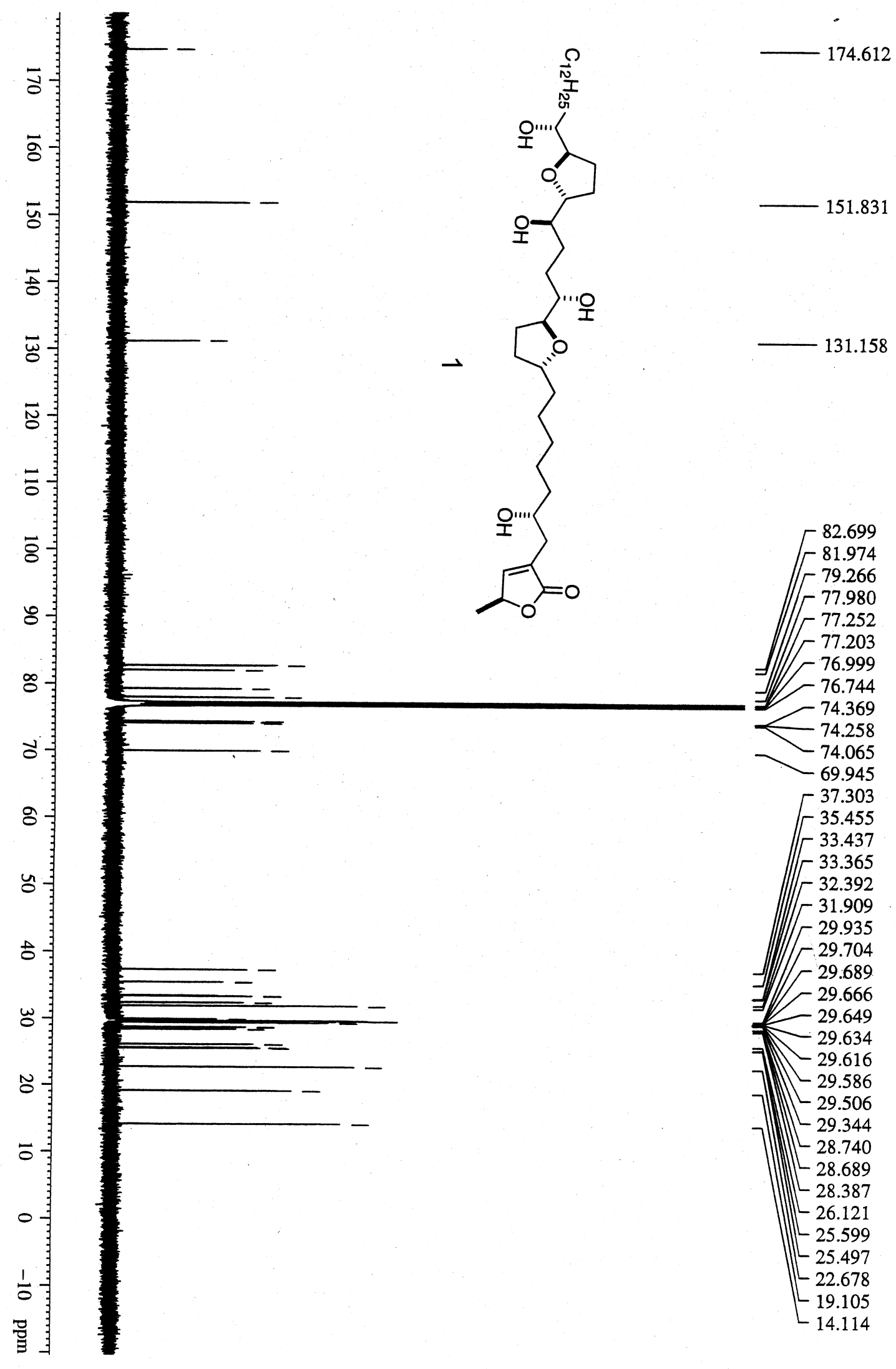

